\title{
Restoring Debt Sustainability After Crises: Implications for the Fiscal Mix
}

\author{
Emanuele Baldacci, Sanjeev Gupta, and \\ Carlos Mulas-Granados
}




\title{
IMF Working Paper
}

Fiscal Affairs Department

\section{Restoring Debt Sustainability After Crises: Implications for the Fiscal Mix}

\author{
Prepared by Emanuele Baldacci, Sanjeev Gupta, and Carlos Mulas-Granados ${ }^{1}$
}

October 2010

\begin{abstract}
This Working Paper should not be reported as representing the views of the IMF.

The views expressed in this Working Paper are those of the author(s) and do not necessarily represent those of the IMF or IMF policy. Working Papers describe research in progress by the author(s) and are published to elicit comments and to further debate.
\end{abstract}

This paper analyzes the experience of 99 advanced and developing economies in restoring fiscal sustainability during 1980-2008 after banking crises, which led to large accumulation of public debt. It finds that successful debt reductions have relied chiefly on generation of large primary surpluses in postcrisis years through current expenditure cuts. These savings have been accompanied by growthpromoting measures and a supportive monetary policy stance. While these results are consistent with the existing literature, the paper finds that revenue-raising measures increased the likelihood of successful consolidation in countries that faced large adjustment needs after the crisis. This reflects the fall in effectiveness of spending cuts when deficit reduction needs are large independent of initial tax ratios.

JEL Classification Numbers: G18, H30, H50

Keywords: Debt Sustainability, Fiscal Policy, Banking Crisis, Survival Analysis.

Authors’ E-Mail Addresses: $\quad$ ebaldacci@imf.org; sgupta@imf.org; cmulasgranados@ccee.ucm.es

\footnotetext{
${ }^{1}$ Carlos Mulas-Granados is a professor of economics at Complutense University, fellow of the ICEI Research Institute, and the Executive Director of the IDEAS Foundation in Madrid. We are indebted to Ignazio Angeloni, Carlo Cottarelli, Alessandro Fontana, Federico Giammusso, Mark Horton, Javier Kapsoli, Vladimir Klyuev, Jiri Jonas, Troy Matheson, and David Romer for helpful comments on earlier drafts of the paper. We would like to acknowledge excellent research assistance from John Piotrowski. The usual disclaimer applies.
} 
Contents

I. Introduction

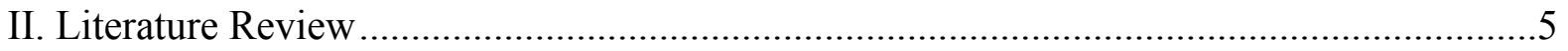

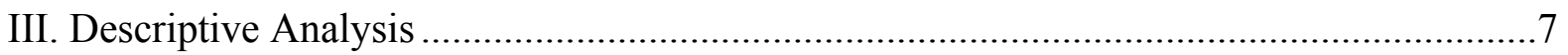

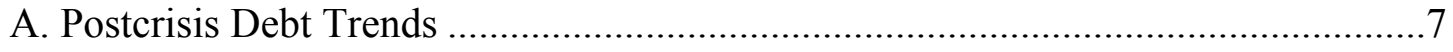

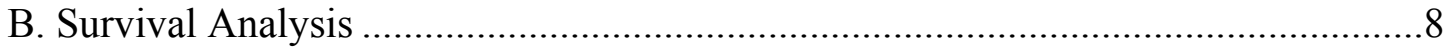

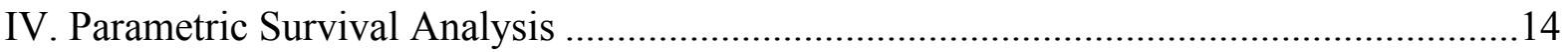

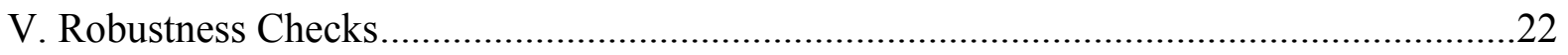

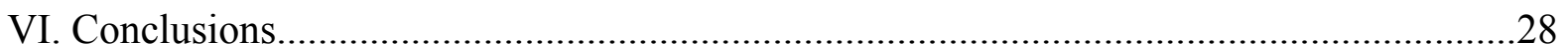

Tables

1. Success and Duration of Debt Recovery Episodes ...........................................................10

2. Success and Duration of Debt Recovery Episodes by Country Group .................................11

3. Success and Duration of Debt Recovery Episodes: "Absolute Debt Target”.......................13

4. Parametric Estimation of Proportional Hazard Model: "Absolute Debt Target" (General Baseline Model) .....................................................................................18

5. Parametric Estimation of Proportional Hazard Model: "Absolute Debt Target"

(Fiscal Composition Model)

6. Parametric Estimation of Proportional Hazard Model: "Absolute Debt Target" (Fiscal Composition Model) - Controlling for Size of Adjustment and GDP Growth ................20

7. Parametric Estimation of Proportional Hazard Model: "Absolute Debt Target"

(Fiscal Composition Model) - Controlling for Size of Adjustment and GDP Growth ...21

8. Parametric Estimation of Proportional Hazard Model: Robustness (1) -

"Absolute Debt Target" at 80/50 Percent of GDP …………….....................................23

9. Parametric Estimation of Proportional Hazard Model: Robustness (2) -

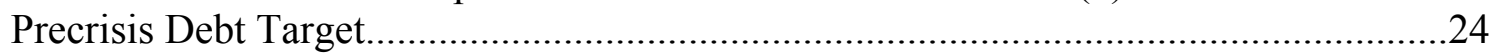

10. Parametric Estimation of Proportional Hazard Model: Robustness (3)-

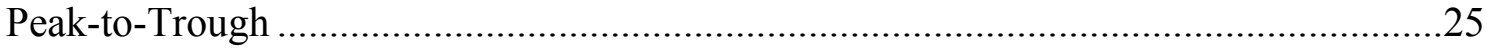

11. Parametric Estimation of Proportional Hazard Model: Robustness (4) -

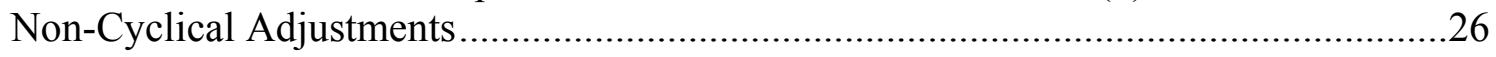

12. Parametric Estimation of Continuous Model: Robustness (5) Change in Debt-to-GDP Ratio in the Aftermath of the Crisis

Figures

1. Distribution of Debt Reduction Episodes by Debt Consolidation Size ..................................8

2. Debt Reduction Episodes, Initial Conditions, and Characteristics of Fiscal

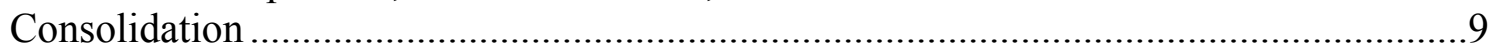

3. Cox-Snell Residuals to Evaluate Fit of Three Regression Models ......................................17

Appendixes

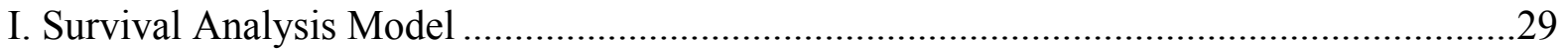

References. 


\section{INTRODUCTION}

Many countries around the world have accumulated large public debt in the aftermath of the global financial crisis. ${ }^{2}$ Debt accumulation reflects revenue losses resulting from economic effects of the crisis, and to a lesser extent, exceptional fiscal stimulus and financial sector support measures (IMF, 2010). This is particularly the case in advanced economies, where debt is projected to rise from an average of about 73 percent of GDP at end-2007 to about 108 percent of GDP at end-2015. This level of debt was only reached after World War II (Cottarelli and Schaechter, 2010). Moreover, the debt surge is occurring at a time when pressure from age-related spending (e.g., pensions and health care) is building up in many countries (IMF, 2009d). Public debt has also increased in some emerging economies (e.g., in Central and Eastern Europe) during the recession, although the bulk of these economies have not been hit as hard as advanced economies, reflecting their relatively healthier fiscal positions before the crisis. Nonetheless, emerging economies tend to have a lower debt tolerance, owing to narrower and more volatile revenue bases, and are exposed to spillover from solvency risks in advanced sovereigns.

The increase in fiscal vulnerabilities following a banking crisis has been highlighted by the literature. Studies have shown that banking crises have large fiscal consequences (Freydl, 1999; IMF, 2009a; 2009b; 2009d; Laeven and Valencia (2008); and Rogoff and Reinhart (2009)). For example, Rogoff and Reinhart found that government debt on average rose by 86 percent in the three years following a banking crisis in a sample of historical episodes, while Laeven and Valencia estimated that the average fiscal cost of banking crises (net of recoveries) was slightly less than 15 percent of GDP in the last three decades. More recently, Baldacci, Gupta, and Mulas-Granados (2009) reported that in the period covered by Laeven and Valencia the average peak-to-trough increase in the public debt-to-GDP ratio was about 40 percentage points.

Higher public debt raises solvency risks, constrains the capacity to use fiscal policy as a countercyclical tool, and can increase borrowing costs for sovereigns (IMF, 2009d). Ultimately, the increase in public debt may reduce output growth and productivity (IMF, 2010). As economies recover from the recession, therefore, the challenge for governments is to regain fiscal health through budget consolidation and pro-growth structural reforms to reduce public debt.

\footnotetext{
${ }^{2}$ In this paper, public debt refers to the consolidated general government debt where data are available, otherwise central government debt. In some countries, public debt should include significant quasi-fiscal activities of state-owned companies and off-budget entities and contingent fiscal liabilities. While the latter are important aspects of fiscal sustainability, they are not included in the analysis of the paper due to data limitations. Furthermore, in some countries, financial assets owned by the government are subtracted from gross debt to estimate net debt. However, we do not use the concept of net debt in this paper because of difficulties in obtaining consistent data across countries.
} 
However, reducing high levels of public debt after the recent crisis can be challenging. The legacy of the crisis on potential output and the unprecedented simultaneous increase in public debt levels worldwide make this effort particularly demanding (Alesina and Ardagna, 2009). Lowering high public debt to a sustainable level calls for large improvements in the structural primary balance and a favorable dynamic of the growth- interest rate differential. The latter could be difficult to achieve in the aftermath of a global banking crisis. This is consistent with the evidence on previous instances of postcrisis debt reduction. In the Baldacci, Gupta, and Mulas-Granados study, only 12 percent of the countries were able to reduce their debt to precrisis levels 16 years after the end of the crisis.

Against this background, the questions that motivated this study are:

- What factors explain the success of public debt consolidations after banking crises?

- Why are some countries faster than others in reducing public debt to prudent levels?

\begin{abstract}
We apply survival analysis to a sample of 100 banking crisis episodes that occurred between 1980 and 2008. At the outset, we study patterns of postcrisis debt stabilization in the sample. We then carry out a parametric analysis to assess the determinants of successful debt reductions after a banking crisis. ${ }^{3}$ In particular, we investigate the role of fiscal policy composition, taking into account accompanying monetary policy and changes in other economic variables during the consolidation period.
\end{abstract}

Our baseline results define a prudent debt level as an "absolute debt target." As returning to the precrisis public debt level may prove insufficiently ambitious for countries that had high debt ratios prior to the crisis, we define specific thresholds of 60 percent of GDP for advanced economies and 40 percent of GDP for emerging market economies reflecting the perceived higher risk for them. This is consistent with the literature on fiscal sustainability, which derives targets for the ratio of public debt to GDP to measure success, independently of the debt level before the crisis (Cottarelli and Viñals, 2009; IMF, 2010). The 60 percent of GDP target for advanced economies is also the median debt-to-GDP ratio in advanced economies in the precrisis period.

We use three definitions of success:

- $\quad$ Complete success - A full attainment of the absolute target.

- Partial success - a reduction by half in the distance between the debt value in the first year after the banking crisis and the target.

\footnotetext{
${ }^{3}$ Note that episodes of debt reduction are considered "successful" if debt levels remained within an interval of one standard deviation around the predefined threshold in the following four years. About 71 percent of successful episodes maintained their debt levels within those limits.
} 
- $\quad$ Limited success - A minimum of 10 percent reduction in this distance.

We complement this analysis with various robustness tests. We examine the impact of alternative debt targets and definitions of success to ensure that our results do not depend on these assumptions. The remainder of this paper is organized as follows: Section 2 reviews the relevant literature. Section 3 describes the dataset used in the analysis. Section 4 reports the findings of the parametric analysis, and Section 5 discusses the robustness of these results. The concluding section summarizes the findings and discusses their policy implications.

\section{LiterATURE REVIEW}

The success of fiscal adjustment strategies in reducing public debt is influenced by the size of fiscal consolidation. ${ }^{4}$ Giavazzi and Pagano (1996), and Giavazzi, Jappelli, and Pagano (2000) find that large consolidations are important for success. ${ }^{5}$ They show that sizable improvements in the structural primary balance signal a regime change, and thus have a positive impact on private sector expectations and consumption behavior. When initial debt is high, as in most advanced and some emerging market economies today, a credible and sustained improvement in the primary balance can spur economic growth, which in turn can help achieve faster debt reduction (IMF, 2009d). The growth spurt stems from a reduction in distortions associated with high levels of taxation to finance elevated debt levels, the wealth effect enjoyed by consumers expecting a decline in the future tax burden, the increase in labor supply from lower taxes and spending (Alesina and Ardagna, 2009), and the beneficial effect of lower interest rates on capital accumulation triggered by public debt reduction, particularly when global sovereign bond supply is expanding (Baldacci and Kumar, 2010).

The composition of the adjustment is also relevant. Alesina and Perotti $(1995,1996)$; McDermott and Wescott (1996); Alesina, Perotti, and Tavares (1998); Alesina, Ardagna, Perotti, and Schiantarelli (1999); and Alesina and Ardagna (2009) show that expenditure cuts increase the likelihood of reducing public debt, in particular when these cuts are concentrated on public transfers (e.g., pensions, subsidies and other entitlements) and government wages. They also find that the composition of fiscal adjustment is more important than its size in reducing the stock of public debt and generating expansionary effects on output. In these studies, spending cuts are found to be more likely than tax increases to stimulate output growth during the fiscal adjustment period.

\footnotetext{
${ }^{4}$ For a definition of fiscal sustainability, see Willcox (1989), Bohn (1995), Cuddington (1997), Chalk and Hemming (2000); IMF (2002), and Cassimon et al. (2008).

${ }^{5}$ Note that in all these studies, success is defined as a reduction of the debt-to-GDP ratio in the aftermath of the adjustment episode.
} 


\section{Sustained fiscal consolidation efforts tend to be associated with successful debt} reductions. This result has been stressed in many studies, including by Von Hagen, Hallett, and Straucht (2001), Maroto and Mulas-Granados (2002, 2007), and Gupta, et al. (2005). More persistent adjustment efforts signal the authorities' commitment to debt consolidation Many authors (e.g., Perotti (1999); Von Hagen, Hallett, and Straucht (2001); and Lambertini and Tavares (2001)) have emphasized the role that positive initial fiscal conditions, initial economic growth, monetary conditions and exchange rate devaluations play in the likelihood of success during fiscal adjustment episodes.

\section{Decisions regarding the timing, the duration, the size, and the composition of} adjustments are usually subject to institutional and political constraints. Among them, the influence of the cabinet's ideology on fiscal policy (Perotti and Kontopoulus, 2002; Mulas-Granados, 2003, 2006); the impact of the electoral system and the budget process (Persson and Tabellini, 1999; Hallerberg and Von Hagen, 1997; Von Hagen, Hallett, and Straucht, 2001), and the proximity of elections (Alesina, Cohen, and Roubini, 1992; and Mulas-Granados, 2002 and 2007; Buti and Van den Noord, 2003) are important. More stable governments and stronger fiscal institutions (including well-designed fiscal rule frameworks) are more likely to remove the deficit bias in fiscal policy and can help achieve lower debt (IMF, 2009e). In contrast, high fragmentation in decision-making can have negative implications on the budget, making fiscal adjustment more difficult and eventually leading to higher debt (Roubini and Sachs, 1989; Grilli, Masciandaro, and Tabellini, 1991; and MulasGranados, 2003).

\section{However, the above literature has not focused on the challenge of regaining debt sustainability after banking crises. On the one hand, it would be expected that most factors identified in the literature on effective fiscal consolidations are at work in the aftermath of banking crises. On the other hand, unwinding of large debt accumulated after these crises could require a different fiscal policy mix in light of the uncertainty about growth and financial sector health that typically follows these episodes and the need for large adjustment. ${ }^{6}$ This is compounded in the case of the current crisis by the twin challenge of fiscal adjustment and increased debt rollover risks across a number of countries in the world, which may have negative implications for interest rates and make debt reduction more difficult to achieve. Furthermore, it is now recognized that policy response to financial crises is critical in reducing crisis length and increasing postcrisis growth (Baldacci, Gupta, and Mulas-Granados, 2009) and this could affect the likelihood of public debt reduction. ${ }^{7}$}

\footnotetext{
${ }^{6}$ In principle, the same effects could be found in fiscal consolidations that are sizeable. We leave this issue for another study while focusing on post-banking crisis episodes in this paper.

${ }^{7}$ Longer crises tend to be associated with larger permanent negative impacts on output and productivity which in turn may also affect postcrisis growth prospects. This can make the challenge of lowering debt more ambitious and require a larger improvement in the primary balance.
} 
The following sections explore the probability of achieving successful fiscal consolidations as defined above by using survival analysis. ${ }^{8}$

\section{DesCRIPTIVe AnAlysis}

In this paper, we use the sample of banking crises compiled by Laeven and Valencia (2008). They define banking crises as periods in which a country's corporate and financial sectors experience a large number of defaults and financial institutions and corporations face great difficulties in meeting contractual obligations. Using a mixture of objective data and subjective assessments, they identify 124 systemic banking crises over the period 1970 2008. We dropped 24 of them due to insufficient fiscal data in the WEO and GFS databases. As a consequence, our sample covers 100 banking crises in 99 advanced and developing countries.

There are two alternative methods to analyze the evolution of public debt in the aftermath of banking crises. The first approach entails looking at the change in debt-toGDP ratios after the crisis and describing debt reduction characteristics (e.g., timing, size, and composition). A second option is to define a threshold to identify successful debt consolidations cases and describe the features associated with these episodes. We use both approaches in the following sections.

\section{A. Postcrisis Debt Trends}

First, we analyze changes in the debt-to-GDP ratio in our dataset. In 65 out of 100 episodes, public debt levels at the end of the banking crisis were higher than before the crisis started. This number rises to 89 episodes if the debt level three years after the start of the crisis is compared to debt before the crisis. Overall, almost 90 percent of episodes left a legacy of higher debt.

About a decade after the end of the crisis, debt ratios fell only in 59 percent of the cases. However, in 40 percent of these episodes, debt was still higher than in the immediate aftermath of the crisis. Postcrisis fiscal consolidation lowered debt by up to 20 percentage points of GDP in 56 percent of the cases, but in more than a quarter of episodes, governments managed to reduce public debt between 20 and 40 percentage points of GDP (Figure 1).

Larger consolidations were associated with high initial levels of debt as adjustment needs became more pressing in these countries (Figure 2). Larger debt reduction is also correlated with more long-lasting fiscal consolidation efforts (Figure 2, Panel b),

\footnotetext{
${ }^{8}$ Among the studies that have used survival analysis to study public finances, there are Gupta et al. (2005); Von Hagen, Hallet, and Strauch (2001); and Maroto and Mulas-Granados (2008).
} 
expenditure-based adjustments ${ }^{9}$ (Figure 2, Panel c), and the contribution of tax revenues to total public revenues (Figure 2, Panel d).

\section{Figure 1. Distribution of Debt Reduction Episodes by Debt Consolidation Size 1/}

(as a Share of Episodes with Postcrisis Debt Reduction)

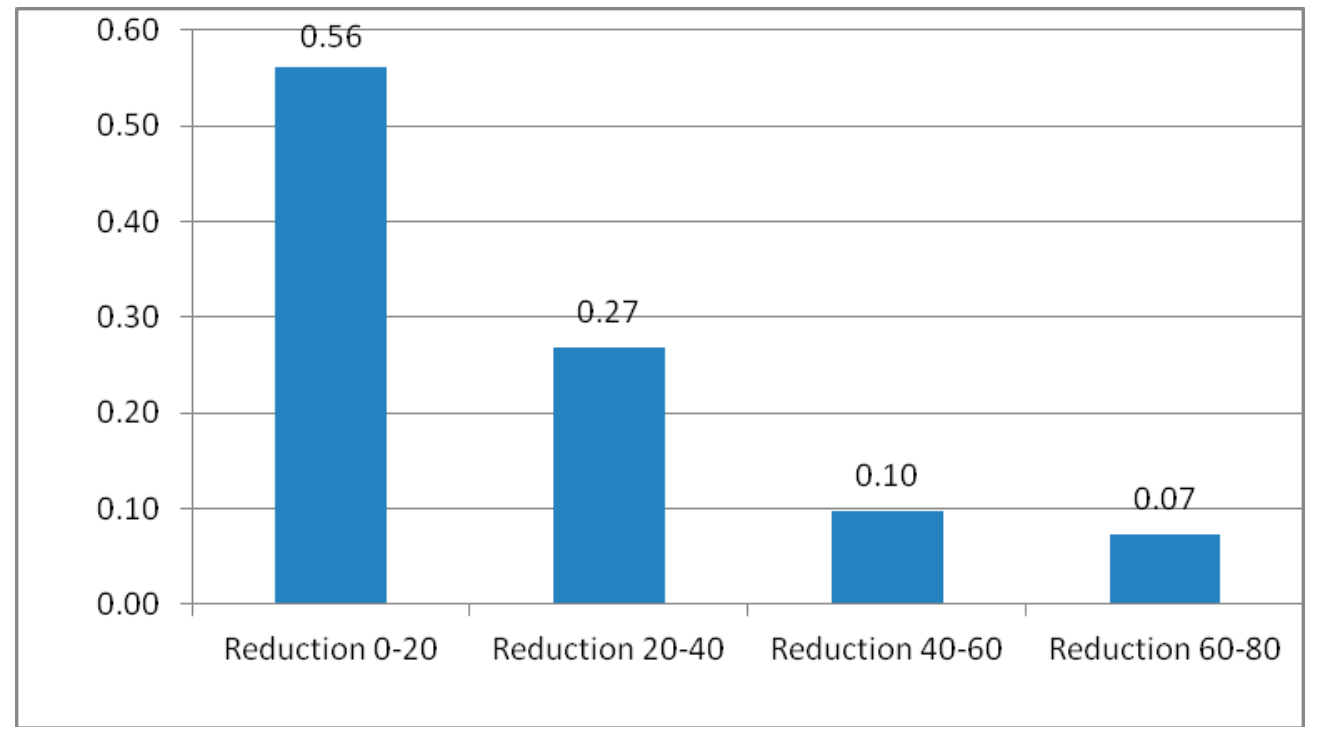

Source: Authors' calculations.

1/ Debt reduction measured in percent of GDP. Debt consolidation calculated by subtracting debt 12 years after the start of the crisis to debt at the end of the crisis.

\section{B. Survival Analysis}

Next we turn to episodes of successful and unsuccessful debt consolidation. We generate a dummy variable that takes value zero every year after an episode of banking crisis in which public debt level (as a percentage of GDP) is above the "absolute target" (60 percent of GDP for advanced economies and 40 percent of GDP for emerging markets). ${ }^{10}$ This variable takes value of one when public debt is equal or lower than the threshold. Using the years in which

\footnotetext{
${ }^{9}$ The quality of fiscal adjustments is measured by the contribution of cyclically adjusted current primary expenditures as a percent of GDP to the reduction in the fiscal deficit in percent of GDP achieved in each consolidation year. We take this definition from Von Hagen, Hallett, and Strauch (2001).

${ }^{10}$ Note that in roughly one-fifth of the countries in our sample debt levels remained below the "absolute debt target" both before and after the banking crises. These were typically low-income countries in Africa and Latin America that have relatively small debt-to-ratios, in part due to various initiatives launched since the mid-1990s to extend debt relief to them.
} 
debt remains above the threshold, we create a new variable called "Duration" that represents the length of the (successful) debt consolidation period (see Appendix I for a discussion of survival analysis). We generate 972 observations (net of missing data points), distributed among 100 episodes of banking crises. The minimum length of a debt-recovery episode is one year and the maximum is 24 years.

\section{Figure 2. Debt Reduction Episodes, Initial Conditions, and Characteristics of Fiscal Consolidation 1/}

1.a. Debt reduction and initial debt

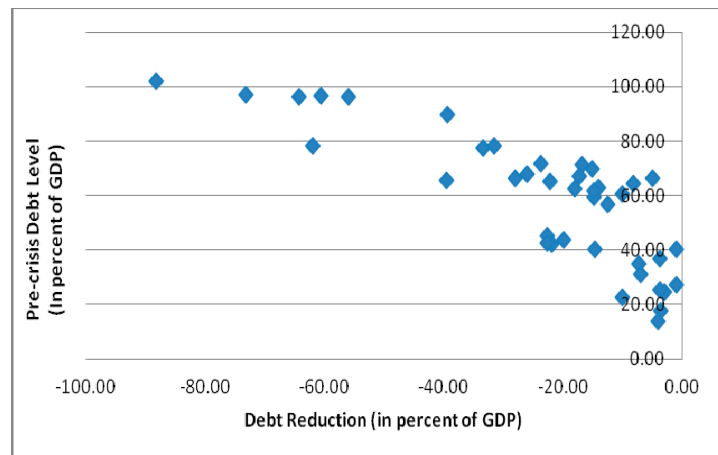

1.c. Debt reduction and quality of adjustments

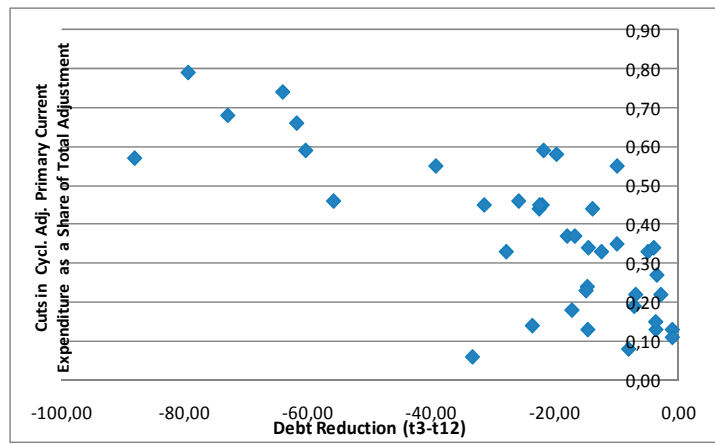

Source: Authors' calculations.

1/ Debt reduction measured in percent of GDP. Debt consolidation calculated by subtracting debt 12 years after the start of the crisis to debt at the end of the crisis. On average, the crisis lasted two years.

It is worth noting that in $\mathbf{5 7}$ percent of the episodes, debt was within the "absolute debt target" before the banking crisis started. In 62 percent of these episodes, debt rose beyond the target as a consequence of the crisis. This reflects both the impact on revenue of potential output losses as well the fiscal cost of the crisis-response measures. Table 1 presents basic 
statistics for the duration of fiscal consolidation and the probability of success for the "absolute debt target" and an alternative "precrisis debt target."11

Under the "absolute debt target" criterion, the average length of a successful debt recovery episode (that is, time taken to reach the target debt level) is about 10 years. This translates into a low probability of success for debt consolidations in the sample. As we relax the definition of success, the duration shortens. For example, the average duration of partially successful episodes (that is, a fall in debt equivalent to 50 percent of the required debt reduction to reach the target debt level) is slightly more than seven years and the average duration of limited success episodes (reducing debt by 10 percent of the required adjustment) is less than six years.

Table 1. Success and Duration of Debt Recovery Episodes

\begin{tabular}{lccccc}
\hline & \multicolumn{2}{c}{ Duration (in years) } & & \multicolumn{2}{c}{ Success (as a share of episodes) } \\
\cline { 2 - 3 } \cline { 5 - 6 } Absolute debt target 1/ & Mean & Std. Dev. & & Mean & Std. Dev. \\
\hline Complete success & 9.88 & 4.011 & & 0.075 & 0.257 \\
Partial success & 7.35 & 4.218 & & 0.111 & 0.314 \\
Limited success & 5.85 & 4.702 & & 0.189 & 0.359 \\
Precrisis debt target & & & & & \\
Complete success & 9.62 & 5.692 & & 0.066 & 0.249 \\
Partial success & 7.12 & 4.959 & & 0.097 & 0.296 \\
Limited success & 5.68 & 4.598 & & 0.128 & 0.335 \\
\hline
\end{tabular}

Source: Authors' calculations.

1/ Reducing debt to 60 percent of GDP in advanced economies and 40 percent of GDP in emerging economies.

Under the "precrisis debt target," the average length of a successful debt recovery episode is $91 / 2$ years. This is slightly less than the time needed to reduce debt to the $60 / 40$ percent of GDP target. In episodes of partial/limited success, duration is seven years and six years, respectively. Reaching the absolute debt target "takes only half a year longer than reaching the" precrisis debt target. This implies that in the sample, precrisis debt levels were not much different from the prudent debt level.

In Table 2, we find that for OECD countries, results are quite different. These countries benefit from both stronger institutions (e.g., stronger fiscal frameworks and public financial management systems) and larger revenue bases, which could have allowed them to achieve

\footnotetext{
${ }^{11}$ The latter is set at the level of the debt-to-GDP ratio in the year before the beginning of the crisis.
} 
debt reduction more easily than other countries in the sample. ${ }^{12}$ This is the case even for highly indebted OECD countries (see below). However, in these countries, reaching the "absolute debt target" takes two more years than regaining their precrisis debt, reflecting high initial public debt prior to the crisis episodes.

Table 2. Success and Duration of Debt Recovery Episodes by Country Group

\begin{tabular}{|c|c|c|c|c|}
\hline \multirow[b]{2}{*}{ Absolute debt target $1 /$} & \multicolumn{2}{|c|}{$\begin{array}{l}\text { Duration OECD } \\
\text { (in years) }\end{array}$} & \multicolumn{2}{|c|}{$\begin{array}{c}\text { Success OECD } \\
\text { (as a share of episodes) }\end{array}$} \\
\hline & Mean & Std. Dev. & Mean & Std. Dev. \\
\hline Complete success & 11.45 & 4.599 & 0.062 & 0.344 \\
\hline Partial success & 9.43 & 4.021 & 0.102 & 0.358 \\
\hline Limited success & 6.97 & 4.767 & 0.167 & 0.376 \\
\hline \multicolumn{5}{|l|}{ Precrisis debt target } \\
\hline Complete success & 9.22 & 6.152 & 0.095 & 0.257 \\
\hline Partial success & 6.81 & 5.028 & 0.124 & 0.283 \\
\hline \multirow[t]{2}{*}{ Limited success } & 5.13 & 5.511 & 0.181 & 0.321 \\
\hline & \multicolumn{2}{|c|}{$\begin{array}{c}\text { Duration Non-OECD } \\
\text { (in years) }\end{array}$} & \multicolumn{2}{|c|}{$\begin{array}{c}\text { Success Non-OECD } \\
\text { (as a share of episodes) }\end{array}$} \\
\hline Absolute debt target $1 /$ & Mean & Std. Dev. & Mean & Std. Dev. \\
\hline Complete success & 9.49 & 5.040 & 0.077 & 0.331 \\
\hline Partial success & 7.70 & 4.882 & 0.112 & 0.356 \\
\hline Limited success & 6.48 & 4.562 & 0.179 & 0.389 \\
\hline \multicolumn{5}{|l|}{ Precrisis debt target } \\
\hline Complete success & 9.89 & 5.628 & 0.101 & 0.327 \\
\hline Partial success & 7.70 & 4.997 & 0.133 & 0.330 \\
\hline Limited success & 6.48 & 4.560 & 0.172 & 0.376 \\
\hline
\end{tabular}

Source: Authors' calculations.

1/ Reducing debt to 60 percent of GDP in advanced economies and 40 percent of GDP in emerging economies.

\footnotetext{
${ }^{12}$ This result is consistent with findings in Von Hagen, Hallet, and Strauch (2001).
} 
The history of banking crises is full of contagion effects (which typically have a regional component) and reputation asymmetries (normally linked to the degree of economic development). This may be reflected in the duration of debt recovery episodes in the aftermath of banking crises. More importantly, public debt dynamics may follow different paths depending on the initial fiscal conditions, the size of the fiscal deterioration, and the budget composition during and after the banking crisis.

Table 3 reports the success probability by crisis characteristics, initial fiscal conditions and adjustment policies. Only statistics for the "absolute debt target" are reported. ${ }^{13}$ The following can be observed:

- $\quad$ Length of banking crisis. ${ }^{14}$ Achieving debt reduction in countries that were hit by long-lasting banking crises tends to take longer than in countries affected by short crisis episodes. This is attributable to permanent income losses which are larger when crises last longer. ${ }^{15}$ As economic growth takes time to resume affecting recovery of revenues, debt consolidation is more difficult to achieve.

- Initial levels of debt. We use different variables to capture two different potential impacts: one that accounts for the initial stock of debt prior to the crisis $;{ }^{16}$ and another that reflects the newly created debt as a consequence of the crisis. ${ }^{17}$ Results differ significantly.

\footnotetext{
${ }^{13}$ Descriptive statistics for the alternative "precrisis debt target" are similar to those reported in the text and available from the authors upon request.

14 This is measured by the length in years of the banking crisis.

${ }^{15}$ Baldacci, Gupta, and Mulas-Granados (2009) show that duration of banking crises is linked to output recovery. It is shorter when fiscal stimulus policies are implemented during the crisis.

16 Countries are classified in the "High Initial Debt" group when their debt-to-GDP ratio in the year before the start of the crisis was above the median debt of the sample. The opposite applies to "Low Initial Debt."

${ }^{17}$ The amount of new debt generated during the crisis is measured as a percentage of the initial level of debt of each country prior to the crisis.
} 
Table 3. Success and Duration of Debt Recovery Episodes: "Absolute Debt Target" 1/, 2/

\begin{tabular}{|c|c|c|c|c|c|c|c|c|c|}
\hline \multirow[b]{2}{*}{ Long bank crisis } & \multicolumn{2}{|c|}{ Duration } & \multicolumn{2}{|c|}{ Success } & \multirow[b]{2}{*}{ Short bank crisis } & \multicolumn{2}{|c|}{ Duration } & \multicolumn{2}{|c|}{ Success } \\
\hline & Mean & Std. Dev. & Mean & Std. Dev. & & Mean & Std. Dev. & Mean & Std. Dev. \\
\hline Complete success & 10.923 & 5.513 & 0.060 & 0.242 & Complete success & 7.732 & 4.502 & 0.093 & 0.254 \\
\hline Partial success & 8.955 & 4.853 & 0.091 & 0.273 & Partial success & 6.077 & 3.405 & 0.147 & 0.333 \\
\hline \multirow[t]{2}{*}{ Limited success } & 7.607 & 4.622 & 0.111 & 0.337 & Limited success & 5.356 & 3.216 & 0.158 & 0.345 \\
\hline & \multicolumn{2}{|c|}{ Duration } & \multicolumn{2}{|c|}{ Success } & & \multicolumn{2}{|c|}{ Duration } & \multicolumn{2}{|c|}{ Success } \\
\hline High debt stock & Mean & Std. Dev. & Mean & Std. Dev. & Low debt stock & Mean & Std. Dev. & Mean & Std. Dev. \\
\hline $\begin{array}{l}\text { Complete success } \\
\text { Partial success } \\
\text { Limited success }\end{array}$ & $\begin{array}{l}8.545 \\
6.656 \\
5.578\end{array}$ & $\begin{array}{l}5.478 \\
4.463 \\
3.621\end{array}$ & $\begin{array}{l}0.101 \\
0.138 \\
0.162\end{array}$ & $\begin{array}{l}0.302 \\
0.344 \\
0.371\end{array}$ & $\begin{array}{l}\text { Complete success } \\
\text { Partial success } \\
\text { Limited success }\end{array}$ & $\begin{array}{l}11.112 \\
9.367 \\
7.845\end{array}$ & $\begin{array}{l}5.354 \\
5.172 \\
5.189\end{array}$ & $\begin{array}{l}0.055 \\
0.071 \\
0.112\end{array}$ & $\begin{array}{l}0.232 \\
0.211 \\
0.389\end{array}$ \\
\hline Limited success & \multicolumn{2}{|c|}{ Duration } & \multicolumn{2}{|c|}{ Success } & & \multicolumn{2}{|c|}{ Duration } & \multicolumn{2}{|c|}{ Success } \\
\hline High new debt & Mean & Std. Dev. & Mean & Std. Dev. & Low new debt & Mean & Std. Dev. & Mean & Std. Dev. \\
\hline $\begin{array}{l}\text { Complete success } \\
\text { Partial success } \\
\text { Limited success }\end{array}$ & $\begin{array}{l}11.145 \\
9.234 \\
7.825\end{array}$ & $\begin{array}{l}5.611 \\
5.134 \\
5.298\end{array}$ & $\begin{array}{l}0.074 \\
0.094 \\
0.113\end{array}$ & $\begin{array}{l}0.210 \\
0.299 \\
0.334\end{array}$ & $\begin{array}{l}\text { Complete success } \\
\text { Partial success } \\
\text { Limited success }\end{array}$ & $\begin{array}{l}8.433 \\
6.576 \\
5.625\end{array}$ & $\begin{array}{l}5.621 \\
4.578 \\
3.934\end{array}$ & $\begin{array}{l}0.101 \\
0.143 \\
0.152\end{array}$ & $\begin{array}{l}0.367 \\
0.342 \\
0.381\end{array}$ \\
\hline Limited success & \multicolumn{2}{|c|}{ Duration } & \multicolumn{2}{|c|}{ Success } & & \multicolumn{2}{|c|}{ Duration } & \multicolumn{2}{|c|}{ Success } \\
\hline Large fiscal adjustment & Mean & Std. Dev. & Mean & Std. Dev. & Small fiscal adjustment & Mean & Std. Dev. & Mean & Std. Dev. \\
\hline $\begin{array}{l}\text { Complete success } \\
\text { Partial success } \\
\text { Limited success }\end{array}$ & $\begin{array}{l}8.578 \\
6.567 \\
5.589\end{array}$ & $\begin{array}{l}5.112 \\
4.489 \\
3.633\end{array}$ & $\begin{array}{l}0.100 \\
0.142 \\
0.160\end{array}$ & $\begin{array}{l}0.309 \\
0.342 \\
0.388\end{array}$ & $\begin{array}{l}\text { Complete success } \\
\text { Partial success } \\
\text { Limited success }\end{array}$ & $\begin{array}{l}11.232 \\
9.356 \\
7.452\end{array}$ & $\begin{array}{l}5.832 \\
5.287 \\
5.439\end{array}$ & $\begin{array}{l}0.043 \\
0.069 \\
0.103\end{array}$ & $\begin{array}{l}0.211 \\
0.287 \\
0.323\end{array}$ \\
\hline Limited success & \multicolumn{2}{|c|}{ Duration } & \multicolumn{2}{|c|}{ Success } & & \multicolumn{2}{|c|}{ Duration } & \multicolumn{2}{|c|}{ Success } \\
\hline High quality adjustment & Mean & Std. Dev. & Mean & Std. Dev. & Low quality adjustment & Mean & Std. Dev. & Mean & Std. Dev. \\
\hline $\begin{array}{l}\text { Complete success } \\
\text { Partial success } \\
\text { Limited success }\end{array}$ & $\begin{array}{l}9.355 \\
7.923 \\
6.921\end{array}$ & $\begin{array}{l}4.410 \\
4.554 \\
4.524\end{array}$ & $\begin{array}{l}0.079 \\
0.111 \\
0.147\end{array}$ & $\begin{array}{l}0.265 \\
0.304 \\
0.343\end{array}$ & $\begin{array}{l}\text { Complete success } \\
\text { Partial success } \\
\text { Limited success }\end{array}$ & $\begin{array}{l}10.224 \\
8.321 \\
7.245\end{array}$ & $\begin{array}{l}5.576 \\
4.088 \\
4.124\end{array}$ & $\begin{array}{l}0.067 \\
0.098 \\
0.121\end{array}$ & $\begin{array}{l}0.287 \\
0.234 \\
0.321\end{array}$ \\
\hline
\end{tabular}

Source: Authors' calculations.

Note: These tables are based on dummy variables for each category. Episodes are classified as Long/Short; High/Low; or Big/Small taking the median value of the variable as a reference.

1/ Reducing debt to 60 percent of GDP in advanced economies and 40 percent of GDP in emerging economies.

2/ Duration in years and success as a share of episodes. 
- Countries with a high level of initial debt experience a faster debt reduction. ${ }^{18}$ Countries facing large fiscal solvency risks stemming from elevated debt levels appear to be more willing to implement drastic measures in the postcrisis period to lower their fiscal deficits, while countries with more limited fiscal challenges "muddle through" the crisis.

- Higher levels of debt accumulated during the banking crisis (compared to the precrisis period) require three to four years more to bring debt under control, thereby lowering the probability of success. This is because higher debt levels trigger a heavy increase in interest payments, raise the size of the needed improvement in the primary balance and make fiscal adjustments more difficult.

- $\quad$ Size of fiscal adjustment.${ }^{19}$ Countries that implemented a sizable improvement in their primary fiscal balance during the postcrisis years were able to reduce their debt faster and also benefitted from ensuing economic recovery and lower credit risk premia (that reduced the interest rate-growth differential).

- Quality of fiscal adjustment. The composition of fiscal consolidation also matters; high-quality, expenditure-based fiscal adjustments lead to shorter debt consolidation periods (almost by one year) and increase the likelihood of success as found in the literature.

\section{Parametric Survival Analysis}

In this section, we assess the determinants of successful debt reduction in the aftermath of banking crises. We use a Cox regression model (see Appendix I) that is equivalent to the standard linear regression in the context of survival analysis; here the duration is measured in terms of the length of a successful debt reduction period. The probability of failing to reduce public debt within the target is regressed on a vector of determinants. This includes two sets of variables.

- Control variables and fiscal policy mix. We include variables that emerged from the descriptive analysis as the most relevant for successful debt reduction. These comprise length of the banking crisis preceding the adjustment episode, debt accumulated during the crisis, ${ }^{20}$ quality of fiscal adjustment during the consolidation

\footnotetext{
${ }^{18}$ See Von Hagen, Hallet, and Strauch (2001) for a similar result in a sample of OECD countries' fiscal adjustment episodes. In these episodes, fiscal consolidation is also more likely to be started when fiscal conditions are bleak, leading to forced adoption of bolder measures.

${ }^{19}$ This variable is measured by the change in the cyclically adjusted primary budget balance in percent of GDP. Positive changes imply a reduction in the deficit.

${ }^{20}$ We use this variable instead of initial public debt levels as it captures better the deterioration in fiscal conditions resulting from the crisis.
} 
period, and a dummy for an OECD country). ${ }^{21}$ In contrast to previous studies, we also include an interaction between the quality of adjustment and a measure of fiscal adjustment size in the aftermath of the crisis. The rationale for including this interaction variable is that in countries that need large adjustments in the cyclically adjusted primary balance to achieve the debt target spending cuts alone may not be sufficient to generate the needed fiscal consolidation. This implies that the adjustment in these countries may need to be a balanced combination of spending cuts and revenue increases in comparison with countries where fiscal consolidation needs are more limited. ${ }^{22}$

- Accompanying policies. We control for private investment as a share of total investment and interest rates on deposits. Higher private investment could result from structural reforms to support the business sector, thereby promoting private-sector led growth. This in turn could help reduce the fiscal deficit by raising revenue and increasing the likelihood of success in reducing debt. ${ }^{23}$ Higher interest rates, reflecting tighter monetary policy rates, are expected to have an opposite effect by increasing debt service cost and affecting growth and investment negatively.

\section{Results confirm the importance of the fiscal policy mix for successful debt reduction.} Table 4 reports the results for the different definitions of success (complete, partial, and limited success) under the "absolute debt target." These results can be summarized as follows:

- $\quad$ Consistent with our assumptions, debt consolidation is less likely when debt accumulated during the crisis is large and after long banking crises.

- $\quad$ The duration of debt consolidation is shorter when fiscal adjustments in the postcrisis years cut current expenditures. These results confirm that expenditure savings are key to regaining debt sustainability. However, in countries where the adjustment size is large, successful debt reduction is delivered by a combination of spending cuts and revenue generating measures. In our sample, when change in the cyclically adjusted primary balance in the postcrisis period is larger than 11 percent of GDP, the total effect of the spending-based quality of adjustment variable on the probability of debt

\footnotetext{
${ }^{21}$ The latter dummy captures economic as well as institutional differences in these countries compared to emerging and low-income countries.

${ }^{22}$ We also estimate the model without the interaction variable to check the robustness of the results. The findings are consistent with the preferred model in the text, but the goodness of fit is lower. We also try an interaction between the quality of adjustment and size of debt build up during the crisis which yields similar results as the model presented in the text.

${ }^{23}$ This variable also allows us to control for post-crisis permanent output losses that could limit potential GDP through lower private investment.
} 
consolidation turns negative. This implies that revenue-based deficit reduction strategies tend to be more successful in these countries.

- Debt reduction is also more successful when fiscal adjustment is combined with accommodative monetary policy. Lower interest rates stimulate investment and can help spur growth if credible fiscal consolidation aims at reducing solvency risks. Fiscal consolidation is also more successful when private investment returns through the positive effect on growth.

There are two channels through which the fiscal policy mix affects the probability of successful fiscal adjustment. First, fiscal adjustments based on an appropriate combination of expenditure cuts and revenue increases allow countries to sustain persistent fiscal consolidations and larger debt reductions. This reflects the scope for large fiscal savings from the adoption of fiscal measures that improve the composition of the budget. Second, an appropriately balanced fiscal policy mix can boost output growth and help lower credit risk premia, thereby reducing the interest rate-growth differential component of debt dynamics.

Table 4 reports results of the regression model estimated with three different techniques. In order to discriminate which of these methods fits data better, we tested their power through graphic analysis of the Cox-Snell residuals. As can be observed in Figure 3, the Weibull model satisfies the exponential requirement most of the time, except for larger residuals. This confirms that the Weibull model should be our preferred model.

In a second step of the econometric analysis, we run regressions for the Weibull model. We include the third set of right-hand side variables, which aims to capture the effects of budget composition on the probability of debt reduction. ${ }^{24}$ We include the following: (i) tax revenues (as a percentage of total public revenues); (ii) spending on goods and services (as a percentage of total public spending); (iii) spending on social transfers (as a percentage of total public spending); and (iv) average public investment (also as a percentage of total public spending).

\section{Results confirm the above findings and also provide new policy messages not discussed in previous studies (Table 5).}

- Raising tax revenues (as a share of total public revenues) in the aftermath of the crisis (i.e., during the debt consolidation period) increases the likelihood of reducing public debt. This reflects the contribution of more stable revenue sources to the budget. ${ }^{25}$

\footnotetext{
${ }^{24} \mathrm{We}$ include these variables as a percentage of cyclically adjusted total revenues or total expenditures to avoid the problem of collinearity with other fiscal variables. Cyclically adjusted variables are obtained using the methodology in Blanchard (1990).

${ }^{25}$ This result was first found for emerging market economies and low-income countries. To make sure that the presence of these countries was not impacting our results, we also estimated the equation by dropping these countries. Results are consistent with our initial findings, and are available from authors upon request.
} 
Reducing the share of goods and services in total expenditure is also significantly related to shorter and more successful fiscal adjustments. Results show that in episodes where the share of this spending increases, the likelihood of debt reduction falls drastically.

Further, the results are consistent with previous findings on the determinants of successful fiscal adjustments.

- Relying less on transfers shortens the duration of adjustment periods, increasing the likelihood of debt reduction. This is because spending on transfers is not easily reversible after a crisis (despite unwinding of automatic stabilizers such as unemployment insurance as growth resumes) and tends to impose a heavy burden on the budget over time.

- Increasing the share of public investment raises the likelihood of successful debt reduction by shifting the composition of the budget toward pro-growth programs.

We also explore further the channels through which the fiscal policy mix affects the likelihood of debt consolidation. In Table 6 we present the results of our baseline model including the size of fiscal adjustment as a control variable. This implies that the other determinants in the model are capturing the impact of the long-term interest rate-growth difference on debt dynamics. Results show that including a control for fiscal adjustment size does not change the previous findings and only confirm the importance of the fiscal policy mix for successful debt reduction, as well as the importance of revenue contributions for large fiscal consolidations. The composition of adjustment affects the probability of successful debt reduction through its impact on growth and by lowering interest rates. Table 7 presents a model where we also control for growth, assessing the impact of the determinants of fiscal consolidation on the portion of debt dynamics related to long-term interest rates on sovereign debt. The results confirm the importance of the adjustment mix and the expenditure and revenue composition variables.

Figure 3. Cox-Snell Residuals to Evaluate Fit of Three Regression Models
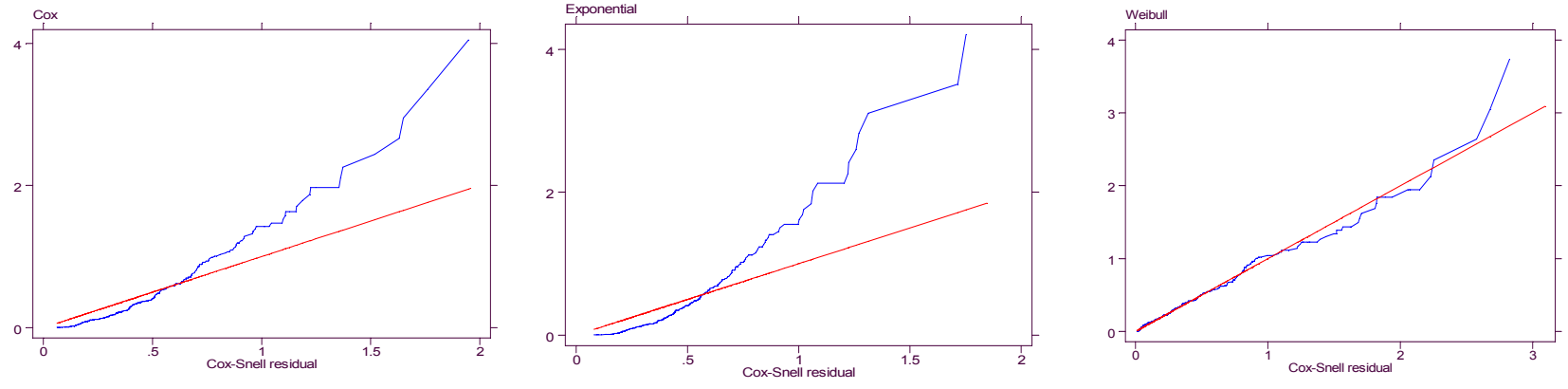

Source: Authors' calculations. 
Table 4. Parametric Estimation of Proportional Hazard Model: “Absolute Debt Target” (General Baseline Model)

\begin{tabular}{|c|c|c|c|c|c|c|c|c|c|}
\hline \multirow[b]{2}{*}{ Duration } & \multicolumn{3}{|c|}{100 percent Threshold } & \multicolumn{3}{|c|}{50 percent Threshold } & \multicolumn{3}{|c|}{10 percent Threshold } \\
\hline & Cox & Exponential & Weibull & Cox & Exponential & Weibull & Cox & Exponential & Weibull \\
\hline Length of banking crisis & $\begin{array}{l}0.177^{* * *} \\
(5.12)\end{array}$ & $\begin{array}{l}0.188^{\star \star \star} \\
(4.93)\end{array}$ & $\begin{array}{l}0.165^{\star \star \star} \\
(5.82)\end{array}$ & $\begin{array}{l}0.125^{\star \star \star} \\
(4.88)\end{array}$ & $\begin{array}{l}0.167^{\star * *} \\
(3.34)\end{array}$ & $\begin{array}{l}0.163^{\star * *} \\
(4.49)\end{array}$ & $\begin{array}{l}0.178^{* * *} \\
(3.34)\end{array}$ & $\begin{array}{l}0.153^{* * *} \\
(2.58)\end{array}$ & $\begin{array}{l}0.176^{\star \star *} \\
(3.48)\end{array}$ \\
\hline \multirow[t]{2}{*}{ Accumulated debt during banking crisis } & $0.819^{* * *}$ & $0.820^{* * *}$ & $0.915^{\star * \star}$ & $0.933^{* * *}$ & $0.902^{* * *}$ & $0.905^{\star \star \star}$ & $0.916^{* * *}$ & $0.713^{* * *}$ & $0.904^{* * *}$ \\
\hline & $(2.95)$ & $(2.93)$ & $(2.97)$ & $(2.76)$ & $(2.58)$ & $(2.63)$ & $(2.55)$ & $(2.91)$ & $(3.04)$ \\
\hline \multirow[t]{2}{*}{ Quality of adjustment } & $-0.209^{* \star \star}$ & $-0.217^{* \star *}$ & $-0.220^{* * *}$ & $-0.193^{* *}$ & $-0.197^{\star \star}$ & $-0.164^{* * *}$ & $-0.289^{* * *}$ & $-0.294^{\star * *}$ & $-0.245^{\star * *}$ \\
\hline & $(-2.18)$ & $(-2.24)$ & $(-2.16)$ & $(-2.05)$ & $(-2.08)$ & $(-2.31)$ & $(-2.45)$ & $(-2.77)$ & $(-2.91)$ \\
\hline \multirow[t]{2}{*}{ Quality of adjustment*Size of fiscal adjustment } & $0.198^{* * *}$ & $0.203^{* * *}$ & $0.205^{\star *}$ & $0.189^{\star \star \star}$ & $0.192^{\star \star \star}$ & $0.172^{\star \star}$ & $0.114^{* * *}$ & $0.110^{\star \star *}$ & $0.111^{* * *}$ \\
\hline & $(2.76)$ & $(2.83)$ & $(2.94)$ & $(2.13)$ & $(2.23)$ & $(2.17)$ & $(2.14)$ & $(2.23)$ & $(2.31)$ \\
\hline \multirow[t]{2}{*}{ OECD country } & $-1.061^{* *}$ & $-1.028^{* * *}$ & $-1.180^{* * *}$ & $-1.580^{* * *}$ & $-1.343^{* * *}$ & $-1.823^{* * *}$ & $-1.166^{* * *}$ & $-1.102^{* * *}$ & $-1.532^{* * *}$ \\
\hline & $(-1.98)$ & $(-2.14)$ & $(-2.16)$ & $(-3.52)$ & $(-3.24)$ & $(-3.65)$ & $(-2.67)$ & $(-2.45)$ & $(-3.24)$ \\
\hline \multirow[t]{2}{*}{ Private investment } & $-0.031^{* * *}$ & $-0.032^{\star * *}$ & $-0.045^{\star * *}$ & $-0.024^{* *}$ & $-0.023^{* * *}$ & $-0.028^{* * *}$ & $-0.017^{*}$ & $-0.023^{* *}$ & $-0.018^{* *}$ \\
\hline & $(-2.42)$ & $(-2.51)$ & $(-2.78)$ & $(-2.01)$ & $(-2.39)$ & $(-2.42)$ & $(-1.95)$ & $(-1.98)$ & $(-1.96)$ \\
\hline \multirow[t]{2}{*}{ Interest rate of bank deposits } & $0.016^{* *}$ & $0.018^{*}$ & $0.019^{* *}$ & $0.012^{* *}$ & $0.013^{* *}$ & $0.016^{*}$ & $0.010^{*}$ & $0.009^{*}$ & $0.011^{*}$ \\
\hline & $(1.96)$ & $(1.88)$ & $(1.92)$ & $(1.98)$ & $(1.99)$ & $(1.84)$ & $(1.69)$ & $(1.82)$ & $(1.74)$ \\
\hline \multirow[t]{2}{*}{ Constant } & & $-3.922^{* * *}$ & $-5.202^{* * *}$ & & $-4.606^{* * *}$ & $-5.506^{* * *}$ & & $-4.106^{* * *}$ & $-5.001^{* * *}$ \\
\hline & & $(-2.98)$ & $(-4.32)$ & & $(-3.66)$ & $(-5.18)$ & & $(-3.72)$ & $(-5.14)$ \\
\hline Wald chi2 & 43.52 & 38.65 & 47.51 & 50.44 & 36.29 & 55.57 & 53.63 & 41.75 & 58.58 \\
\hline No. of failures & 35 & 35 & 35 & 45 & 45 & 45 & & 51 & 51 \\
\hline Number of obs. & 564 & 564 & 564 & 458 & 458 & 458 & 375 & 375 & 375 \\
\hline
\end{tabular}

Source: Authors' calculations.

$\left.{ }^{(* *}\right)$ Significant at a 1 percent level; $\left({ }^{* *}\right)$ significant at a 5 percent level; $\left({ }^{*}\right)$ significant at a 10 percent level. 
Table 5. Parametric Estimation of Proportional Hazard Model: “Absolute Debt Target” (Fiscal Composition Model)

\begin{tabular}{|c|c|c|c|c|c|c|c|c|c|c|c|c|}
\hline \multirow{3}{*}{$\begin{array}{l}\text { Duration } \\
\text { Length of banking crisis }\end{array}$} & \multicolumn{4}{|c|}{100 percent threshold } & \multicolumn{4}{|c|}{50 percent threshold } & \multicolumn{4}{|c|}{10 percent threshold } \\
\hline & \multicolumn{12}{|c|}{ Weibull } \\
\hline & $\begin{array}{l}0.151^{* * *} \\
(5.04)\end{array}$ & $\begin{array}{l}0.190^{* * *} \\
(3.80)\end{array}$ & $\begin{array}{l}0.168^{* * *} \\
(5.14)\end{array}$ & $\begin{array}{l}0.156^{* * *} \\
(4.46)\end{array}$ & $\begin{array}{l}0.160^{* * *} \\
(3.16)\end{array}$ & $\begin{array}{l}0.132^{* * *} \\
(4.61)\end{array}$ & $\begin{array}{l}0.163^{* * *} \\
(3.12)\end{array}$ & $\begin{array}{l}0.169^{* * *} \\
(2.43)\end{array}$ & $\begin{array}{l}0.174^{* * *} \\
(3.22)\end{array}$ & $\begin{array}{l}0.188^{* * *} \\
(3.40)\end{array}$ & $\begin{array}{l}0.140^{* * *} \\
(3.52)\end{array}$ & $\begin{array}{l}0.139^{* * *} \\
(2.88)\end{array}$ \\
\hline Accumulated debt during banking crisis & $\begin{array}{l}0.822^{* * *} \\
(2.91)\end{array}$ & $\begin{array}{l}0.821^{\star * *} \\
(2.45)\end{array}$ & $\begin{array}{l}0.833^{\star *} \\
(2.91)\end{array}$ & $\begin{array}{l}0.907^{* * *} \\
(2.43)\end{array}$ & $\begin{array}{l}0.913^{* * *} \\
(2.25)\end{array}$ & $\begin{array}{l}0.944^{\star * *} \\
(2.56)\end{array}$ & $\begin{array}{l}0.900^{\star \star *} \\
(2.63)\end{array}$ & $\begin{array}{l}0.711^{\star * *} \\
(2.83)\end{array}$ & $\begin{array}{l}0.931^{* \star *} \\
(3.24)\end{array}$ & $\begin{array}{l}0.821^{\star * *} \\
(3.14)\end{array}$ & $\begin{array}{l}0.803^{* * *} \\
(2.82)\end{array}$ & $\begin{array}{l}0.704^{* * *} \\
(2.98)\end{array}$ \\
\hline Quality of adjustment & $\begin{array}{l}-0.282^{\star * \star} \\
(-2.91)\end{array}$ & $\begin{array}{l}-0.250^{\star * \star} \\
(-2.85)\end{array}$ & $\begin{array}{l}-0.238^{* \star *} \\
(-2.47)\end{array}$ & $\begin{array}{l}-0.222^{* * *} \\
(-2.90)\end{array}$ & $\begin{array}{l}-0.244^{* * *} \\
(-2.92)\end{array}$ & $\begin{array}{l}-0.268^{* \star *} \\
(-2.75)\end{array}$ & $\begin{array}{l}-0.283^{\star * *} \\
(-2.63)\end{array}$ & $\begin{array}{l}-0.271^{* \star *} \\
(-2.60)\end{array}$ & $\begin{array}{l}-0.254^{* * *} \\
(-2.92)\end{array}$ & $\begin{array}{l}-0.248^{* \star *} \\
(-2.76)\end{array}$ & $\begin{array}{l}-0.252^{\star \star \star} \\
(-2.12)\end{array}$ & $\begin{array}{l}-0.248^{\star * *} \\
(-2.99)\end{array}$ \\
\hline Quality adjustment*Size of fiscal adjustment & $\begin{array}{l}0.175^{\star * *} \\
(2.36)\end{array}$ & $\begin{array}{l}0.182^{* * *} \\
(2.59)\end{array}$ & $\begin{array}{l}0.187^{* * *} \\
(2.77)\end{array}$ & $\begin{array}{l}0.192^{* * *} \\
(2.81)\end{array}$ & $\begin{array}{l}0.187^{* * *} \\
(3.11)\end{array}$ & $\begin{array}{l}0.167^{* * *} \\
(3.02)\end{array}$ & $\begin{array}{l}0.172^{* * *} \\
(2.51)\end{array}$ & $\begin{array}{l}0.193^{* * *} \\
(3.12)\end{array}$ & $\begin{array}{l}0.173^{* * *} \\
(2.51)\end{array}$ & $\begin{array}{l}0.185^{\star * *} \\
(2.37)\end{array}$ & $\begin{array}{l}0.194^{* * *} \\
(2.67)\end{array}$ & $\begin{array}{l}0.191^{* * *} \\
(2.78)\end{array}$ \\
\hline OECD country & $\begin{array}{l}-1.024^{* * *} \\
(-2.93)\end{array}$ & $\begin{array}{l}-1.010^{* *} \\
(-2.24)\end{array}$ & $\begin{array}{l}-1.155^{\star *} \\
(-2.22)\end{array}$ & $\begin{array}{l}-1.210^{* * *} \\
(-3.34)\end{array}$ & $\begin{array}{l}-1.154^{* * *} \\
(-3.12)\end{array}$ & $\begin{array}{l}-1.310^{* * *} \\
(-3.54)\end{array}$ & $\begin{array}{l}-1.167^{* * *} \\
(-3.60)\end{array}$ & $\begin{array}{l}-1.201^{\star * *} \\
(-2.70)\end{array}$ & $\begin{array}{l}-1.510^{* * *} \\
(-3.32)\end{array}$ & $\begin{array}{l}-1.125^{\star * *} \\
(-3.30)\end{array}$ & $\begin{array}{l}-1.200^{* * *} \\
(3.45)\end{array}$ & $\begin{array}{l}-1.600^{* * *} \\
(-3.44)\end{array}$ \\
\hline Private investment & $\begin{array}{l}-0.019^{* * *} \\
(-2.99)\end{array}$ & $\begin{array}{l}-0.015^{\star *} \\
(-2.19)\end{array}$ & $\begin{array}{l}-0.019^{* *} \\
(-2.22)\end{array}$ & $\begin{array}{l}-0.016^{* * *} \\
(-2.92)\end{array}$ & $\begin{array}{l}-0.010^{* *} \\
(-2.11)\end{array}$ & $\begin{array}{l}-0.012^{* *} \\
(-2.01)\end{array}$ & $\begin{array}{l}-0.007^{* *} \\
(-2.12)\end{array}$ & $\begin{array}{l}-0.013^{* *} \\
(-2.01)\end{array}$ & $\begin{array}{l}-0.011^{* *} \\
(-2.09)\end{array}$ & $\begin{array}{l}-0.017^{* * *} \\
(2.07)\end{array}$ & $\begin{array}{l}-0.012^{* * *} \\
(2.04)\end{array}$ & $\begin{array}{l}-0.013^{\text {** }} \\
(2.12)\end{array}$ \\
\hline Interest rate of bank deposits & $\begin{array}{l}0.011^{* *} \\
(1.97)\end{array}$ & $\begin{array}{l}0.016^{*} \\
(1.78)\end{array}$ & $\begin{array}{l}0.020^{*} \\
(1.85)\end{array}$ & $\begin{array}{l}0.018^{* * *} \\
(1.99)\end{array}$ & $\begin{array}{l}0.011^{*} \\
(1.76)\end{array}$ & $\begin{array}{l}0.013^{*} \\
(1.84)\end{array}$ & $\begin{array}{l}0.010^{*} \\
(1.73)\end{array}$ & $\begin{array}{l}0.014^{* *} \\
(1.98)\end{array}$ & $\begin{array}{l}0.011^{*} \\
(1.77)\end{array}$ & $\begin{array}{l}0.010^{*} \\
(1.89)\end{array}$ & $\begin{array}{l}0.009^{*} \\
(1.87)\end{array}$ & $\begin{array}{l}0.012^{* *} \\
(1.99)\end{array}$ \\
\hline Change in tax revenues $1 /$ & $\begin{array}{l}-0.620^{\star * *} \\
(-3.98)\end{array}$ & & & & $\begin{array}{l}-0.618^{* * *} \\
(-3.93)\end{array}$ & & & & $\begin{array}{l}-0.610^{* * *} \\
(-3.89)\end{array}$ & & & \\
\hline Change in goods \& services expenditures $1 /$ & & $\begin{array}{l}0.330^{* * *} \\
(3.01)\end{array}$ & & & & $\begin{array}{l}0.328^{\star * *} \\
(2.98)\end{array}$ & & & & $\begin{array}{l}0.321^{* * *} \\
(2.97)\end{array}$ & & \\
\hline Change in transfers expenditures $1 /$ & & & $\begin{array}{l}0.216^{* * *} \\
(2.92)\end{array}$ & & & & $\begin{array}{l}0.212^{* * *} \\
(2.75)\end{array}$ & & & & $\begin{array}{l}0.209^{* * *} \\
(2.72)\end{array}$ & \\
\hline Change in public investment expenditures $1 /$ & & & & $\begin{array}{l}0.142^{* * *} \\
(2.88)\end{array}$ & & & & $\begin{array}{l}0.119^{* * *} \\
(2.71)\end{array}$ & & & & $\begin{array}{l}0.116^{\star \star *} \\
(2.62)\end{array}$ \\
\hline Constant & $\begin{array}{l}-6.901^{* * *} \\
(10.70)\end{array}$ & $\begin{array}{l}-5.526^{\star * \star} \\
(-2.88)\end{array}$ & $\begin{array}{l}-8.072^{\star * *} \\
(-2.84)\end{array}$ & $\begin{array}{l}-7.210^{\star \star \star} \\
(-4.41)\end{array}$ & $\begin{array}{l}-6.033^{* * *} \\
(-2.12)\end{array}$ & $\begin{array}{l}-5.568^{* * *} \\
(-2.92)\end{array}$ & $\begin{array}{l}-7.012^{\star * *} \\
(-3.59)\end{array}$ & $\begin{array}{l}-8.032^{\star \star *} \\
(-5.52)\end{array}$ & $\begin{array}{l}-2.263^{\star * *} \\
(2.85)\end{array}$ & $\begin{array}{l}-5.104^{\star * *} \\
(-3.24)\end{array}$ & $\begin{array}{l}-7.024^{* * *} \\
(-3.48)\end{array}$ & $\begin{array}{l}-6.010^{* * *} \\
(-4.82)\end{array}$ \\
\hline $\begin{array}{l}\text { Wald chi2 } \\
\text { No. of failures }\end{array}$ & $\begin{array}{l}47.58 \\
33\end{array}$ & $\begin{array}{l}38.42 \\
32\end{array}$ & $\begin{array}{l}37.31 \\
32\end{array}$ & $\begin{array}{l}40.74 \\
33\end{array}$ & $\begin{array}{l}45.45 \\
43\end{array}$ & $\begin{array}{l}42.60 \\
42\end{array}$ & $\begin{array}{l}49.61 \\
43\end{array}$ & $\begin{array}{l}50.32 \\
43\end{array}$ & $\begin{array}{l}50.21 \\
49\end{array}$ & $\begin{array}{l}53.12 \\
49\end{array}$ & $\begin{array}{l}52.14 \\
48\end{array}$ & $\begin{array}{l}58.23 \\
49\end{array}$ \\
\hline Number of obs. & 543 & 542 & 542 & 543 & 432 & 432 & 445 & 445 & 362 & 362 & 361 & 362 \\
\hline
\end{tabular}

Source: Authors' calculations.

$\left({ }^{* * *}\right)$ Significant at a 1 percent level; $\left({ }^{* *}\right)$ significant at a 5 percent level; $\left({ }^{*}\right)$ significant at a 10 percent level. 
Table 6. Parametric Estimation of Proportional Hazard Model: “Absolute Debt Target” (Fiscal Composition Model)_Controlling for Size of Adjustment

\begin{tabular}{|c|c|c|c|c|c|c|c|c|c|c|c|c|}
\hline \multirow[b]{2}{*}{ Duration } & \multicolumn{4}{|c|}{100 percent threshold } & \multicolumn{4}{|c|}{50 percent threshold } & \multicolumn{4}{|c|}{10 percent threshold } \\
\hline & \multicolumn{12}{|c|}{ Weibull } \\
\hline \multirow{2}{*}{ Length of banking crisis } & $0.152^{\star \star *}$ & $0.193^{\star \star *}$ & $0.166^{\star \star \star}$ & $0.152^{\star \star \star}$ & $0.166^{\star \star \star}$ & $0.130^{\star \star \star}$ & $0.173^{\star \star \star}$ & $0.171^{\star \star *}$ & $0.179^{\star \star \star}$ & $0.187^{\star \star \star}$ & $0.147^{\star \star \star}$ & $0.136^{\star \star \star}$ \\
\hline & $(5.06)$ & $(3.82)$ & $(5.12)$ & $(4.40)$ & $(3.10)$ & $(4.60)$ & $(3.15)$ & $(2.44)$ & $(3.20)$ & $(3.48)$ & $(3.55)$ & $(2.87)$ \\
\hline \multirow[t]{2}{*}{ Accumulated debt during banking crisis } & $0.823^{* * *}$ & $0.820^{\star * *}$ & $0.834^{* *}$ & $0.902^{* * *}$ & $0.912^{* * *}$ & $0.955^{\star * *}$ & $0.901^{* * *}$ & $0.710^{* * *}$ & $0.930^{* * *}$ & $0.810^{* * *}$ & $0.805^{* * *}$ & $0.703^{* * *}$ \\
\hline & $(2.95)$ & $(2.88)$ & $(2.89)$ & $(2.45)$ & $(2.24)$ & $(2.61)$ & $(2.52)$ & $(2.82)$ & $(3.23)$ & $(3.04)$ & $(2.87)$ & $(2.85)$ \\
\hline \multirow[t]{2}{*}{ Size of Adjustment } & $-0.403^{\star * *}$ & $-0.480^{* \star *}$ & $-0.438^{\star \star *}$ & $-0.495^{\star * *}$ & $-0.461^{* * *}$ & $-0.454^{* * *}$ & $-0.452^{\star * *}$ & $-0.420^{\star * *}$ & $-0.478^{\star * \star}$ & $-0.471^{* * *}$ & $-0.495^{\star \star \star}$ & $-0.483^{\star * \star}$ \\
\hline & $(-4.32)$ & $(-4.25)$ & $(-3.74)$ & $(-3.65)$ & $(-3.57)$ & $(-3.82)$ & $(-3.53)$ & $(-3.61)$ & $(-3.86)$ & $(3.72)$ & $(-3.32)$ & $(-3.25)$ \\
\hline \multirow[t]{2}{*}{ Quality of adjustment } & $-0.185^{\star *}$ & $-0.154^{*}$ & $-0.209^{\star *}$ & $-0.123^{*}$ & $-0.142^{*}$ & $-0.177^{*}$ & $-0.188^{* *}$ & $-0.171^{* *}$ & $-0.202^{\star \star *}$ & $-0.209^{\star \star *}$ & $-0.216^{\star \star \star}$ & $-0.203^{\star \star *}$ \\
\hline & $(-1.92)$ & $(-1.78)$ & $(-2.07)$ & $(-1.88)$ & $(-1.91)$ & $(-1.72)$ & $(-2.11)$ & $(-2.19)$ & $(-2.89)$ & $(-2.24)$ & $(-2.14)$ & $(-2.79)$ \\
\hline \multirow[t]{2}{*}{ Quality adjustment*Size of fiscal adjustment } & $0.183^{* * *}$ & $0.171^{* * *}$ & $0.154^{* * *}$ & $0.148^{* * *}$ & $0.152^{* * *}$ & $0.148^{* * *}$ & $0.176^{* *}$ & $0.181^{* *}$ & $0.186^{* * *}$ & $0.193^{* * *}$ & $0.188^{* * *}$ & $0.177^{* * *}$ \\
\hline & $(2.63)$ & $(2.60)$ & $(2.92)$ & $(2.76)$ & $(2.12)$ & $(2.99)$ & $(2.06)$ & $(2.09)$ & $(2.77)$ & $(2.81)$ & $(3.11)$ & $(3.02)$ \\
\hline \multirow[t]{2}{*}{ OECD country } & $-1.043^{* *}$ & $-1.033^{* \star *}$ & $-1.133^{* * *}$ & $-1.501^{* * *}$ & $-1.355^{\star \star \star}$ & $-1.805^{\star \star \star}$ & $-1.170^{\star * *}$ & $-1.042^{\star \star *}$ & $-1.504^{\star * *}$ & $-1.116^{\star * *}$ & $-1.270^{\star \star \star}$ & $-1.709^{\star * \star}$ \\
\hline & $(-1.98)$ & $(-2.18)$ & $(-2.11)$ & $(-3.22)$ & $(-3.16)$ & $(-3.45)$ & $(-2.61)$ & $(-2.75)$ & $(-3.29)$ & $(-3.29)$ & $(-3.03)$ & $(-3.47)$ \\
\hline \multirow[t]{2}{*}{ Private investment } & $-0.019^{* * *}$ & $-0.015^{\star \star *}$ & $-0.019^{\star * *}$ & $-0.016^{* * *}$ & $-0.011^{*}$ & $-0.009^{*}$ & $-0.007^{*}$ & $-0.010^{* *}$ & $-0.011^{* *}$ & $-0.011^{* *}$ & $-0.009^{* *}$ & $-0.008^{* *}$ \\
\hline & $(-2.99)$ & $(-2.89)$ & $(-2.69)$ & $(-2.92)$ & $(-2.21)$ & $(-2.28)$ & $(-2.12)$ & $(-2.11)$ & $(-1.99)$ & $(-2.07)$ & $(-2.04)$ & $(-2.01)$ \\
\hline \multirow[t]{2}{*}{ Interest rate of bank deposits } & $0.011^{*}$ & $0.016^{*}$ & $0.020^{*}$ & $0.011^{* *}$ & $0.018^{*}$ & $0.012^{*}$ & $0.010^{* *}$ & $0.014^{* *}$ & $0.019^{*}$ & $0.012^{*}$ & $0.009^{*}$ & $0.008^{\star}$ \\
\hline & $(1.94)$ & $(1.93)$ & $(1.95)$ & $(1.98)$ & $(1.92)$ & $(1.94)$ & $(1.99)$ & $(1.95)$ & $(1.85)$ & $(1.78)$ & $(1.89)$ & $(1.95)$ \\
\hline \multirow[t]{2}{*}{ Change in tax revenues $1 /$} & $-0.621^{* * *}$ & & & & $-0.519^{* * *}$ & & & & $-0.421^{* * *}$ & & & \\
\hline & $(-2.96)$ & & & & $(-2.92)$ & & & & $(-2.83)$ & & & \\
\hline \multirow[t]{2}{*}{ Change in goods \& services expenditures $1 /$} & & $0.132^{* * *}$ & & & & $0.121^{* *}$ & & & & $0.120^{\star * *}$ & & \\
\hline & & $(2.93)$ & & & & $(2.87)$ & & & & $(2.98)$ & & \\
\hline \multirow[t]{2}{*}{ Change in transfers expenditures $1 /$} & & & $0.218^{* *}$ & & & & $0.119^{* *}$ & & & & $0.146^{* *}$ & \\
\hline & & & $(2.21)$ & & & & $(2.11)$ & & & & $(2.10)$ & \\
\hline \multirow[t]{2}{*}{ Change in public investment expenditures $1 /$} & & & & $0.119^{\star * *}$ & & & & $0.116^{\star * *}$ & & & & $0.110^{\star * \star}$ \\
\hline & & & & $(2.97)$ & & & & $(2.71)$ & & & & $(2.68)$ \\
\hline \multirow[t]{2}{*}{ Constant } & $-6.921^{* * *}$ & $-5.566^{\star \star \star}$ & $-8.070^{* * *}$ & $-7.220^{\star * *}$ & $-6.003^{* \star *}$ & $-5.567^{\star * *}$ & $-7.022^{* * *}$ & $-8.004^{* * *}$ & $-2.262^{* * *}$ & $-5.105^{\star * *}$ & $-7.004^{* * *}$ & $-6.012^{\star * *}$ \\
\hline & $(10.67)$ & $(-3.68)$ & $(-2.99)$ & $(-4.40)$ & $(-3.12)$ & $(-3.67)$ & $(-3.58)$ & $(-5.56)$ & $(3.55)$ & $(-3.14)$ & $(-3.49)$ & $(-4.81)$ \\
\hline Wald chi2 & 47.58 & 38.42 & 37.31 & 40.74 & 45.45 & 42.60 & 49.61 & 50.32 & 50.21 & 53.12 & 52.14 & 58.23 \\
\hline No. of failures & 33 & 32 & 32 & 33 & 43 & 42 & 43 & 43 & 49 & 49 & 48 & 49 \\
\hline Number of obs. & 543 & 542 & 542 & 543 & 432 & 432 & 445 & 445 & 362 & 362 & 361 & 362 \\
\hline
\end{tabular}

Source: Authors' calculations.

$\left({ }^{* * *}\right)$ Significant at a 1 percent level; $\left({ }^{* *}\right)$ significant at a 5 percent level; $\left({ }^{*}\right)$ significant at a 10 percent level. 
Table 7. Parametric Estimation of Proportional Hazard Model: “Absolute Debt Target” (Fiscal Composition Model) - Controlling for Size of Adjustment and GDP Growth

\begin{tabular}{|c|c|c|c|c|c|c|c|c|c|c|c|c|}
\hline \multirow[b]{2}{*}{ Duration } & \multicolumn{4}{|c|}{100 percent threshold } & \multicolumn{4}{|c|}{50 percent threshold } & \multicolumn{4}{|c|}{10 percent threshold } \\
\hline & \multicolumn{12}{|c|}{ Weibull } \\
\hline \multirow{2}{*}{ Length of banking crisis } & $0.156^{\star * *}$ & $0.196^{* * *}$ & $0.176^{* * *}$ & $0.158^{* * *}$ & $0.165^{\star * \star}$ & $0.137^{* * *}$ & $0.168^{* * *}$ & $0.172^{* * *}$ & $0.172^{* * *}$ & $0.189^{* * *}$ & $0.143^{* * *}$ & $0.145^{* * *}$ \\
\hline & $(5.15)$ & $(3.88)$ & $(5.17)$ & $(4.49)$ & $(3.18)$ & $(4.63)$ & $(3.17)$ & $(2.45)$ & $(3.27)$ & $(3.42)$ & $(3.54)$ & $(2.89)$ \\
\hline \multirow[t]{2}{*}{ Accumulated debt during banking crisis } & $0.820^{* * *}$ & $0.832^{\star * *}$ & $0.834^{* *}$ & $0.897^{* * *}$ & $0.902^{* * *}$ & $0.925^{\star * *}$ & $0.911^{* * *}$ & $0.713^{* * *}$ & $0.936^{\star * *}$ & $0.828^{* * *}$ & $0.814^{* * *}$ & $0.725^{\star * *}$ \\
\hline & $(2.92)$ & $(2.66)$ & $(2.93)$ & $(2.54)$ & $(2.34)$ & $(2.67)$ & $(2.69)$ & $(2.85)$ & $(3.27)$ & $(3.15)$ & $(2.84)$ & $(2.99)$ \\
\hline \multirow[t]{2}{*}{ Size of fiscal adjustment } & $-0.495^{\star \star \star}$ & $-0.492^{* * *}$ & $-0.478^{\star * *}$ & $-0.498^{* * *}$ & $-0.492^{* \star *}$ & $-0.484^{\star \star *}$ & $-0.492^{* * *}$ & $-0.488^{* * *}$ & $-0.498^{* * *}$ & $-0.491^{* * *}$ & $-0.495^{\star * *}$ & $-0.493^{* * *}$ \\
\hline & $(-4.38)$ & $(-4.34)$ & $(-3.98)$ & $(-3.87)$ & $(-3.92)$ & $(-3.91)$ & $(-3.83)$ & $(-3.69)$ & $(-3.88)$ & $(3.76)$ & $(-3.72)$ & $(-3.84)$ \\
\hline \multirow[t]{2}{*}{ Quality of adjustment } & $-0.182^{* *}$ & $-0.152^{*}$ & $-0.193^{\star *}$ & $-0.126^{* *}$ & $-0.141^{* *}$ & $-0.173^{* *}$ & $-0.182^{* *}$ & $-0.173^{* *}$ & $-0.212^{* * *}$ & $-0.203^{* * *}$ & $-0.215^{* * *}$ & $-0.208^{* * *}$ \\
\hline & $(-1.95)$ & $(-1.81)$ & $(-2.08)$ & $(-1.99)$ & $(-1.98)$ & $(-1.97)$ & $(-2.10)$ & $(-2.12)$ & $(-2.93)$ & $(-2.34)$ & $(-2.23)$ & $(-2.80)$ \\
\hline \multirow[t]{2}{*}{ Quality adjustment*Size of fiscal adjustment } & $0.118^{* *}$ & $0.116^{*}$ & $0.117^{* *}$ & $0.102^{* *}$ & $0.103^{* *}$ & $0.105^{*}$ & $0.103^{* *}$ & $0.102^{* *}$ & $0.103^{*}$ & $0.105^{*}$ & $0.102^{* *}$ & $0.103^{* *}$ \\
\hline & $(2.11)$ & $(1.90)$ & $(2.07)$ & $(2.06)$ & $(2.05)$ & $(1.85)$ & $(2.02)$ & $(2.00)$ & $(1.83)$ & $(1.86)$ & $(1.92)$ & $(1.95)$ \\
\hline \multirow[t]{2}{*}{ OECD country } & $-1.004^{* * *}$ & $-1.009^{* *}$ & $-1.105^{\star *}$ & $-1.212^{\star * *}$ & $-1.153^{* * *}$ & $-1.309^{* * *}$ & $-1.162^{* * *}$ & $-1.203^{\star * *}$ & $-1.509^{* * *}$ & $-1.120^{* * *}$ & $-1.197^{* * *}$ & $-1.456^{* * *}$ \\
\hline & $(-2.95)$ & $(-2.26)$ & $(-2.26)$ & $(-3.35)$ & $(-3.13)$ & $(-3.55)$ & $(-3.62)$ & $(-2.74)$ & $(-3.33)$ & $(-3.35)$ & $(3.46)$ & $(-3.45)$ \\
\hline \multirow[t]{2}{*}{ Real GDP growth } & $-0.135^{\star * *}$ & $-0.156^{* * *}$ & $-0.158^{* * *}$ & $-0.149^{* * *}$ & $-0.161^{* * *}$ & $-0.156^{* * *}$ & $-0.174^{* * *}$ & $-0.177^{* * *}$ & $-0.175^{* *}$ & $0.192^{* *}$ & $0.179^{* *}$ & $0.124^{* *}$ \\
\hline & $(-2.93)$ & $(-2.87)$ & $(-2.73)$ & $(-2.86)$ & $(-3.13)$ & $(-2.74)$ & $(-3.65)$ & $(-4.54)$ & $(-3.52)$ & $(2.98)$ & $(2.16)$ & $(2.20)$ \\
\hline \multirow[t]{2}{*}{ Private investment } & $-0.018^{* * *}$ & $-0.016^{* *}$ & $-0.017^{* *}$ & $-0.015^{\star * *}$ & $-0.011^{* *}$ & $-0.012^{* *}$ & $-0.009^{* *}$ & $-0.014^{\star *}$ & $-0.012^{* *}$ & $-0.018^{* * *}$ & $-0.013^{* * *}$ & $-0.014^{* * *}$ \\
\hline & $(-2.87)$ & $(-2.25)$ & $(-2.20)$ & $(-2.93)$ & $(-2.23)$ & $(-2.12)$ & $(-2.10)$ & $(-2.11)$ & $(-2.10)$ & $(2.09)$ & $(2.05)$ & $(2.14)$ \\
\hline \multirow[t]{2}{*}{ Interest rate of bank deposits } & 0.012 & $0.017^{*}$ & 0.022 & $0.009^{* *}$ & $0.009^{*}$ & $0.007^{*}$ & $0.007^{*}$ & $0.009^{*}$ & $0.007^{*}$ & $0.008^{*}$ & $0.009^{*}$ & $0.010^{* *}$ \\
\hline & $(0.90)$ & $(1.77)$ & $(1.34)$ & $(1.97)$ & $(1.49)$ & $(1.48)$ & $(1.43)$ & $(1.87)$ & $(1.72)$ & $(1.73)$ & $(1.88)$ & $(1.97)$ \\
\hline \multirow[t]{2}{*}{ Change in tax revenues $1 /$} & $-0.625^{\star * *}$ & & & & $-0.623^{* * *}$ & & & & $-0.615^{* * *}$ & & & \\
\hline & $(-3.97)$ & & & & $(-3.95)$ & & & & $(-3.92)$ & & & \\
\hline \multirow[t]{2}{*}{ Change in goods \& services expenditures $1 /$} & & $0.333^{* *}$ & & & & $0.329^{* *}$ & & & & $0.324^{* * *}$ & & \\
\hline & & $(3.03)$ & & & & $(2.96)$ & & & & $(2.99)$ & & \\
\hline \multirow[t]{2}{*}{ Change in transfers expenditures $1 /$} & & & $0.212^{* * *}$ & & & & $0.215^{* * *}$ & & & & $0.211^{* * *}$ & \\
\hline & & & $(2.92)$ & & & & $(2.83)$ & & & & $(2.77)$ & \\
\hline \multirow[t]{2}{*}{ Change in public investment expenditures $1 /$} & & & & $0.145^{\star * *}$ & & & & $0.124^{* * *}$ & & & & $0.119^{* * *}$ \\
\hline & & & & $(2.89)$ & & & & $(2.72)$ & & & & $(2.63)$ \\
\hline \multirow[t]{2}{*}{ Constant } & $-6.912^{* * *}$ & $-5.534^{* * *}$ & $-8.066^{* * *}$ & $-7.221^{* * *}$ & $-6.045^{* * *}$ & $-5.544^{* * *}$ & $-7.005^{\star * *}$ & $-8.011^{* * *}$ & $-2.248^{* * *}$ & $-5.123^{* * *}$ & $-7.020^{* * *}$ & $-6.008^{* * *}$ \\
\hline & $(10.45)$ & $(-2.98)$ & $(-2.87)$ & $(-4.45)$ & $(-2.45)$ & $(-2.93)$ & $(-3.66)$ & $(-5.57)$ & $(2.57)$ & $(-3.25)$ & $(-3.42)$ & $(-4.80)$ \\
\hline Wald chi2 & 47.57 & 38.44 & 37.32 & 40.73 & 45.46 & 42.62 & 49.63 & 50.33 & 50.26 & 53.13 & 52.10 & 58.29 \\
\hline No. of failures & 33 & 32 & 32 & 33 & 43 & 42 & 43 & 43 & 49 & 49 & 48 & 49 \\
\hline Number of obs. & 543 & 542 & 542 & 543 & 432 & 432 & 445 & 445 & 362 & 362 & 361 & 362 \\
\hline
\end{tabular}

Source: Authors' calculations.

$\left.{ }^{* * *}\right)$ Significant at a 1 percent level; $\left(^{* *}\right)$ significant at a 5 percent level; $\left({ }^{*}\right)$ significant at a 10 percent level. 


\section{Robustness Checks}

\section{As a robustness check of our results, we introduced five modifications in our baseline model.}

- $\quad$ A different absolute definition of debt thresholds (Table 8). The results are robust to an alternative "absolute debt threshold" of 80 percent of GDP for advanced economies and 50 percent of GDP for emerging economies.

- A different relative target (Table 9). A requirement of debt consolidation to at least precrisis levels. Our results hold confirming the importance of revenue contribution to large fiscal adjustments as in the baseline model.

- Different selection criteria (Table 10). Underlying our baseline analysis, there is an assumption about the reference point from which to start counting the number of years that the debt consolidation lasted. In the baseline model, we followed a crisis-to-target approach, that is, we counted debt-to-GDP ratio from the last year of the banking crisis. As a robustness check, we took the alternative definition of peak-to-target, which implies measuring the adjustment from the year in which the debt level peaked during the banking crisis episode. Our results are robust to peak-to-target reference point.

- The introduction of non-cyclically adjusted fiscal variables (Table 11). We replicated the econometric analysis using non-cyclically adjusted fiscal indicators. The statistical significance of our estimations using non adjusted data weakens slightly. But they continue to show that a combination of expenditure savings and revenue enhancing measures are needed for debt consolidations.

- A redefinition of the dependent variable (Table 12). We assessed the determinants of changes in the debt-to-GDP ratio in the decade after the crisis compared to the postcrisis year. Results show that our findings based on the survival analysis are robust to this alternative specification. Using three different estimation methods (OLS, fixed effects, and PCSE), the impact of independent variables has the expected sign and is consistent with the baseline results. The reduction in public debt is larger when fiscal consolidation is based mostly on current expenditure savings measures. However, when adjustments are also accompanied by reforms to boost revenue collection, debt reduction is larger. 
Table 8. Parametric Estimation of Proportional Hazard Model: Robustness (1)_“Absolute Debt Target” at 80/50 Percent of GDP

\begin{tabular}{|c|c|c|c|c|c|c|c|c|c|c|c|c|}
\hline \multirow{2}{*}{ Duration } & \multicolumn{4}{|c|}{100 percent threshold } & \multirow{2}{*}{\multicolumn{4}{|c|}{$\frac{50 \text { percent threshold }}{\text { Weibull }}$}} & \multicolumn{4}{|c|}{10 percent threshold } \\
\hline & & & & & & & & & & & & \\
\hline \multirow[t]{2}{*}{ Length of banking crisis } & $0.152^{* \star *}$ & $0.193^{* * *}$ & $0.166^{* \star *}$ & $0.152^{\star \star \star}$ & $0.166^{\star * *}$ & $0.130^{* * *}$ & $0.173^{* * *}$ & $0.171^{\star \star \star}$ & $0.179^{* * *}$ & $0.187^{\star \star \star}$ & $0.147^{\star \star \star}$ & $0.136^{\star \star *}$ \\
\hline & $(5.06)$ & $(3.82)$ & $(5.12)$ & $(4.40)$ & $(3.10)$ & $(4.60)$ & $(3.15)$ & $(2.44)$ & $(3.20)$ & $(3.48)$ & $(3.55)$ & $(2.87)$ \\
\hline \multirow[t]{2}{*}{ Accumulated debt during banking crisis } & $0.823^{\star * *}$ & $0.820^{\star \star \star}$ & $0.834^{* *}$ & $0.902^{\star * \star}$ & $0.912^{\star * \star}$ & $0.955^{\star \star \star}$ & $0.901^{* * *}$ & $0.710^{\star * *}$ & $0.930^{\star * *}$ & $0.810^{\star * *}$ & $0.805^{\star * \star}$ & $0.703^{\star \star *}$ \\
\hline & $(2.95)$ & $(2.88)$ & $(2.89)$ & $(2.45)$ & $(2.24)$ & $(2.61)$ & $(2.52)$ & $(2.82)$ & $(3.23)$ & $(3.04)$ & $(2.87)$ & $(2.85)$ \\
\hline \multirow[t]{2}{*}{ Quality of fiscal adjustment } & $-0.282^{\star \star \star}$ & $-0.250^{* * *}$ & $-0.238^{* * *}$ & $-0.222^{\star \star *}$ & $-0.244^{\star * \star}$ & $-0.268^{\star \star \star}$ & $-0.283^{\star \star \star}$ & $-0.271^{* * *}$ & $-0.254^{* * *}$ & $-0.248^{* * *}$ & $-0.252^{\star \star \star}$ & $-0.248^{* * *}$ \\
\hline & $(-2.91)$ & $(-2.85)$ & $(-2.47)$ & $(-2.90)$ & $(-2.92)$ & $(-2.75)$ & $(-2.63)$ & $(-2.60)$ & $(-2.92)$ & $(-2.76)$ & $(-2.12)$ & $(-2.99)$ \\
\hline \multirow[t]{2}{*}{ Quality of adjustment*Size of adjustment } & $0.182^{* * *}$ & $0.192^{* * *}$ & $0.178^{* *}$ & $0.188^{\star * \star}$ & $0.164^{\star * \star}$ & $0.168^{* * *}$ & $0.183^{* * *}$ & $0.191^{* \star *}$ & $0.154^{\star \star}$ & $0.149^{* *}$ & $0.151^{\star * \star}$ & $0.146^{* *}$ \\
\hline & $(2.31)$ & $(2.15)$ & $(2.07)$ & $(2.21)$ & $(2.32)$ & $(2.15)$ & $(2.63)$ & $(2.55)$ & $(2.13)$ & $(2.04)$ & $(2.12)$ & $(1.99)$ \\
\hline \multirow[t]{2}{*}{ OECD country } & $0.286^{* * *}$ & $-0.255^{\star * *}$ & $-0.279^{* * *}$ & $-0.224^{* * *}$ & $-0.243^{* * *}$ & $-0.278^{* * *}$ & $-0.289^{* * *}$ & $-0.272^{* * *}$ & $-0.283^{* * *}$ & $-0.295^{\star * *}$ & $-0.297^{* * *}$ & $-0.243^{* * *}$ \\
\hline & $(2.93)$ & $(-2.79)$ & $(-2.70)$ & $(-2.89)$ & $(-2.91)$ & $(-2.79)$ & $(-2.92)$ & $(-2.89)$ & $(-2.88)$ & $(-2.85)$ & $(-2.84)$ & $(-2.81)$ \\
\hline \multirow[t]{2}{*}{ Private investment } & $0.188^{* *}$ & $0.157^{* *}$ & $0.212^{\star *}$ & $0.126^{\star}$ & $0.145^{\star *}$ & $0.197^{* *}$ & $0.175^{\star *}$ & $0.134^{*}$ & $0.219^{\star *}$ & $0.188^{* *}$ & $0.147^{\star}$ & $0.179^{* *}$ \\
\hline & $(2.05)$ & $(1.97)$ & $(2.10)$ & $(1.91)$ & $(1.97)$ & $(1.98)$ & $(1.92)$ & $(1.78)$ & $(2.07)$ & $(2.08)$ & $(2.02)$ & $(2.18)$ \\
\hline \multirow[t]{2}{*}{ Interest rate of bank deposits } & $0.012^{* *}$ & $0.014^{* *}$ & $0.022^{* *}$ & $0.019^{* *}$ & $0.018^{* *}$ & $0.011^{* *}$ & $0.015^{\star *}$ & $0.017^{*}$ & $0.018^{*}$ & $0.017^{* *}$ & $0.018^{* *}$ & $0.019^{* *}$ \\
\hline & $(1.93)$ & $(1.86)$ & $(1.85)$ & $(1.98)$ & $(1.82)$ & $(1.84)$ & $(1.89)$ & $(1.88)$ & $(1.85)$ & $(1.88)$ & $(1.97)$ & $(1.99)$ \\
\hline \multirow[t]{2}{*}{ Change in tax revenues $1 /$} & $-0511^{* * *}$ & & & & $-0.499^{* * *}$ & & & & $-0.488^{* * *}$ & & & \\
\hline & $(-3.24)$ & & & & $(-2.98)$ & & & & $(-2.90)$ & & & \\
\hline \multirow[t]{2}{*}{ Change in goods \& services expenditures $1 /$} & & $0.135^{\star \star \star}$ & & & & $0.132^{\star \star \star}$ & & & & $0.123^{\star \star \star}$ & & \\
\hline & & $(2.96)$ & & & & $(2.88)$ & & & & $(2.45)$ & & \\
\hline \multirow[t]{2}{*}{ Change in transfers expenditures $1 /$} & & & $0.205^{\star \star \star}$ & & & & $0.147^{* * *}$ & & & & $0.112^{* * *}$ & \\
\hline & & & $(2.36)$ & & & & $(2.34)$ & & & & $(2.31)$ & \\
\hline \multirow[t]{2}{*}{ Change in public investment expenditures $1 /$} & & & & $0.123^{* \star *}$ & & & & $0.122^{* \star *}$ & & & & $0.121^{* * *}$ \\
\hline & & & & $(2.98)$ & & & & $(2.84)$ & & & & $(2.68)$ \\
\hline \multirow[t]{2}{*}{ Constant } & $-6.905^{\star \star \star}$ & $-5.008^{\star \star *}$ & $-8.019^{\star \star \star}$ & $-7.211^{* \star *}$ & $-6.025^{\star \star \star}$ & $-5.508^{\star \star \star}$ & $-6.214^{\star \star *}$ & $-7.107^{\star \star \star}$ & $-4.208^{* \star \star}$ & $-5.119^{\star \star \star}$ & $-6.207^{\star * \star}$ & $-6.014^{\star * *}$ \\
\hline & $(10.81)$ & $(-7.94)$ & $(-2.99)$ & $(-4.43)$ & $(-2.98)$ & $(-2.93)$ & $(-3.41)$ & $(-5.90)$ & $(3.45)$ & $(-3.18)$ & $(-3.31)$ & $(-4.90)$ \\
\hline Wald chi2 & 47.69 & 38.56 & 37.44 & 40.72 & 45.46 & 42.60 & 49.58 & 50.22 & 50.31 & 53.12 & 52.22 & 58.13 \\
\hline No. of failures & 33 & 32 & 32 & 33 & 43 & 42 & 43 & 43 & 49 & & 48 & 49 \\
\hline Number of obs. & 543 & 542 & 542 & 543 & 432 & 432 & 445 & 445 & 362 & 362 & 361 & 362 \\
\hline
\end{tabular}

Source: Authors' calculations.

1/ Figures in percent of cyclically adjusted total revenues or total expenditures. Changes are calculated as follows: we subtract the value of the variable in the last year of the adjustment episode from its value in the first year in which the debt consolidation starts.

$\left({ }^{* *}\right)$ Significant at a 1 percent level; $\left({ }^{* *}\right)$ significant at a 5 percent level; $\left({ }^{*}\right)$ significant at a 10 percent level. 
Table 9. Parametric Estimation of Proportional Hazard Model: Robustness (2)—Precrisis Debt Target

\begin{tabular}{|c|c|c|c|c|c|c|c|c|c|c|c|c|}
\hline \multirow{3}{*}{$\begin{array}{l}\text { Duration } \\
\text { Length of banking crisis }\end{array}$} & \multicolumn{4}{|c|}{100 percent threshold } & \multicolumn{4}{|c|}{50 percent threshold } & \multicolumn{4}{|c|}{10 percent threshold } \\
\hline & \multicolumn{12}{|c|}{ Weibull } \\
\hline & $\begin{array}{l}0.151^{* * *} \\
(5.04)\end{array}$ & $\begin{array}{l}0.190^{\star * *} \\
(3.80)\end{array}$ & $\begin{array}{l}0.168^{\star \star *} \\
(5.14)\end{array}$ & $\begin{array}{l}0.156^{\star \star *} \\
(4.46)\end{array}$ & $\begin{array}{l}0.160^{* * *} \\
(3.16)\end{array}$ & $\begin{array}{l}0.132^{* * *} \\
(4.61)\end{array}$ & $\begin{array}{l}0.163^{* * *} \\
(3.12)\end{array}$ & $\begin{array}{l}0.169^{\star \star *} \\
(2.43)\end{array}$ & $\begin{array}{l}0.174^{* * *} \\
(3.22)\end{array}$ & $\begin{array}{l}0.188^{* * *} \\
(3.40)\end{array}$ & $\begin{array}{l}0.140^{* * *} \\
(3.52)\end{array}$ & $\begin{array}{l}0.139^{* \star *} \\
(2.88)\end{array}$ \\
\hline \multirow[t]{2}{*}{ Accumulated debt during banking crisis } & $0.822^{* \star \star}$ & $0.821^{\star \star \star}$ & $0.833^{* *}$ & $0.907^{* \star \star}$ & $0.913^{\star * *}$ & $0.944^{\star * *}$ & $0.900^{* * *}$ & $0.711^{\star \star \star}$ & $0.931^{* * *}$ & $0.821^{\star \star \star}$ & $0.803^{\star * \star}$ & $0.704^{\star * \star}$ \\
\hline & $(2.91)$ & $(2.45)$ & $(2.91)$ & $(2.43)$ & $(2.25)$ & $(2.56)$ & $(2.63)$ & $(2.83)$ & $(3.24)$ & $(3.14)$ & $(2.82)$ & $(2.98)$ \\
\hline \multirow[t]{2}{*}{ Quality of fiscal adjustment } & $-0.283^{\star \star *}$ & $-0.252^{\star \star \star}$ & $-0.249^{\star * *}$ & $-0.225^{\star \star \star}$ & $-0.245^{\star \star *}$ & $-0.269^{\star \star \star}$ & $-0.284^{\star *}$ & $-0.272^{\star *}$ & $-0.255^{\star \star \star}$ & $-0.259^{\star \star *}$ & $-0.235^{\star \star}$ & $-0.260^{* * *}$ \\
\hline & $(-2.94)$ & $(-2.89)$ & $(-2.14)$ & $(-2.92)$ & $(-2.93)$ & $(-2.76)$ & $(-2.15)$ & $(-2.22)$ & $(-2.94)$ & $(-2.77)$ & $(-2.12)$ & $(-2.99)$ \\
\hline \multirow[t]{2}{*}{ Quality of adjustment ${ }^{*}$ Size of adjustment } & $0.188^{* *}$ & $0.157^{\star}$ & $0.212^{\star \star}$ & $0.126^{*}$ & $0.145^{\star \star}$ & $0.197^{\star *}$ & $0.175^{\star *}$ & $0.134^{*}$ & $0.219^{* *}$ & $0.128^{*}$ & $0.147^{*}$ & $0.179^{*}$ \\
\hline & $(1.95)$ & $(1.81)$ & $(2.10)$ & $(1.91)$ & $(1.97)$ & $(1.98)$ & $(1.92)$ & $(1.78)$ & $(2.07)$ & $(1.88)$ & $(1.92)$ & $(1.78)$ \\
\hline \multirow[t]{2}{*}{ OECD country } & $-1.044^{\star *}$ & $-1.030^{* * *}$ & $-1.135^{\star \star \star}$ & $-1.511^{* * *}$ & $-1.356^{\star \star \star}$ & $-1.812^{\star * \star}$ & $-1.167^{\star * *}$ & $-1.001^{\star \star \star}$ & $-1.514^{\star * *}$ & $-1.105^{\star \star \star}$ & $-1.201^{\star \star *}$ & $-1.679^{\star \star *}$ \\
\hline & $(-1.93)$ & $(-2.23)$ & $(-2.24)$ & $(-3.34)$ & $(-3.10)$ & $(-3.58)$ & $(-2.65)$ & $(-2.70)$ & $(-3.30)$ & $(-3.31)$ & $(3.45)$ & $(-3.44)$ \\
\hline \multirow[t]{2}{*}{ Private investment } & $-0.019^{* * *}$ & $-0.015^{\star * *}$ & $-0.019^{* * *}$ & $-0.016^{\star * *}$ & $-0.011^{*}$ & $-0.019^{* * *}$ & $-0.017^{\star * *}$ & $-0.010^{\star * *}$ & $-0.011^{* *}$ & $-0.011^{* *}$ & $-0.012^{\star *}$ & $-0.008^{* *}$ \\
\hline & $(-2.99)$ & $(-2.89)$ & $(-2.69)$ & $(-2.92)$ & $(-2.21)$ & $(-2.28)$ & $(-2.32)$ & $(-2.31)$ & $(-2.19)$ & $(-2.07)$ & $(-2.04)$ & $(-2.01)$ \\
\hline \multirow[t]{2}{*}{ Interest rate of bank deposits } & $0.011^{*}$ & $0.016^{*}$ & $0.020^{*}$ & $0.019^{* *}$ & $0.008^{*}$ & $0.008^{*}$ & $0.005^{* *}$ & $0.008^{*}$ & $0.006^{*}$ & $0.007^{* *}$ & $0.008^{* *}$ & $0.007^{*}$ \\
\hline & $(1.90)$ & $(1.83)$ & $(1.85)$ & $(1.95)$ & $(1.82)$ & $(1.84)$ & $(1.99)$ & $(1.85)$ & $(1.85)$ & $(1.98)$ & $(1.99)$ & $(1.95)$ \\
\hline \multirow[t]{2}{*}{ Change in tax revenues $1 /$} & $-0.602^{\star \star \star}$ & & & & $-0.509^{\star * *}$ & & & & $-0.443^{\star * *}$ & & & \\
\hline & $(-2.97)$ & & & & $(-2.92)$ & & & & $(-2.85)$ & & & \\
\hline \multirow[t]{2}{*}{ Change in goods \& services expenditures $1 /$} & & $0.153^{* * *}$ & & & & $0.145^{\star \star \star}$ & & & & $0.142^{\star \star *}$ & & \\
\hline & & $(3.04)$ & & & & $(2.87)$ & & & & $(2.99)$ & & \\
\hline \multirow[t]{2}{*}{ Change in transfers expenditures $1 /$} & & & $0.218^{* * *}$ & & & & $0.159^{* *}$ & & & & $0.148^{* *}$ & \\
\hline & & & $(2.22)$ & & & & $(2.17)$ & & & & $(2.16)$ & \\
\hline \multirow[t]{2}{*}{ Change in public investment expenditures $1 /$} & & & & $0.118^{* \star *}$ & & & & $0.119^{\text {***}}$ & & & & $0.111^{* * *}$ \\
\hline & & & & $(2.98)$ & & & & $(2.79)$ & & & & $(2.72)$ \\
\hline \multirow[t]{2}{*}{ Constant } & $-6.911^{* * *}$ & $-5.516^{* * *}$ & $-8.170^{\star * *}$ & $-7.110^{\star \star \star}$ & $-6.013^{\star * *}$ & $-5.517^{\star * *}$ & $-7.122^{\star \star *}$ & $-8.014^{\star * *}$ & $-2.212^{\star \star \star}$ & $-5.115^{\star * *}$ & $-7.104^{\star * *}$ & $-6.011^{* * *}$ \\
\hline & $(10.62)$ & $(-3.68)$ & $(-2.94)$ & $(-4.40)$ & $(-3.12)$ & $(-3.67)$ & $(-3.59)$ & $(-5.56)$ & $(3.50)$ & $(-3.14)$ & $(-3.39)$ & $(-4.21)$ \\
\hline Wald chi2 & 47.60 & 38.48 & 37.34 & 40.76 & 45.46 & 42.62 & 49.64 & 50.38 & 50.22 & 53.32 & 52.16 & 58.35 \\
\hline No. of failures & 33 & 32 & 32 & 33 & 43 & 42 & 43 & 43 & 49 & 49 & 48 & 49 \\
\hline Number of obs. & 543 & 542 & 542 & 543 & 432 & 432 & 445 & 445 & 362 & 362 & 361 & 362 \\
\hline
\end{tabular}

Source: Authors' calculations.

1/ Figures in percent of cyclically adjusted total revenues or total expenditures. Changes are calculated as follows: we subtract the value of the variable in the last year of the adjustment episode from its value in the first year in which the debt consolidation starts.

$\left.{ }^{* * *}\right)$ Significant at a 1 percent level; $\left({ }^{* *}\right)$ significant at a 5 percent level; $\left({ }^{*}\right)$ significant at a 10 percent level. 
Table 10. Parametric Estimation of Proportional Hazard Model: Robustness (3)-Peak-to-Trough

\begin{tabular}{|c|c|c|c|c|c|c|c|c|c|c|c|c|}
\hline \multirow{3}{*}{$\frac{\text { Duration }}{\text { Length of banking crisis }}$} & \multicolumn{4}{|c|}{100 percent threshold } & \multirow{2}{*}{\multicolumn{4}{|c|}{$\begin{array}{c}50 \text { percent threshold } \\
\text { Weibull }\end{array}$}} & \multicolumn{4}{|c|}{10 percent threshold } \\
\hline & & & & & & & & & & & & \\
\hline & $\begin{array}{l}0.160^{\star \star *} \\
(3.16)\end{array}$ & $\begin{array}{l}0.132^{\star \star *} \\
(4.61)\end{array}$ & $\begin{array}{l}0.163^{\star \star *} \\
(3.12)\end{array}$ & $\begin{array}{l}0.169^{\star * *} \\
(2.43)\end{array}$ & $\begin{array}{l}0.150^{\star * *} \\
(5.04)\end{array}$ & $\begin{array}{l}0.190^{\star \star *} \\
(3.80)\end{array}$ & $\begin{array}{l}0.168^{\star \star *} \\
(5.14)\end{array}$ & $\begin{array}{l}0.156^{* * *} \\
(4.46)\end{array}$ & $\begin{array}{l}0.174^{\star * *} \\
(3.22)\end{array}$ & $\begin{array}{l}0.188^{\star \star *} \\
(3.40)\end{array}$ & $\begin{array}{l}0.140^{\star \star *} \\
(3.52)\end{array}$ & $\begin{array}{l}0.139^{\star * *} \\
(2.88)\end{array}$ \\
\hline Accumulated debt during banking crisis & $\begin{array}{l}0.913^{* * *} \\
(2.25)\end{array}$ & $\begin{array}{l}0.944^{* * *} \\
(2.56)\end{array}$ & $\begin{array}{l}0.900^{* * *} \\
(2.63)\end{array}$ & $\begin{array}{l}0.711^{* * *} \\
(2.83)\end{array}$ & $\begin{array}{l}0.822^{* * *} \\
(2.91)\end{array}$ & $\begin{array}{l}0.821^{* * *} \\
(2.45)\end{array}$ & $\begin{array}{l}0.833^{* *} \\
(2.91)\end{array}$ & $\begin{array}{l}0.907^{* * *} \\
(2.43)\end{array}$ & $\begin{array}{l}0.931^{* * *} \\
(3.24)\end{array}$ & $\begin{array}{l}0.821^{* * *} \\
(3.14)\end{array}$ & $\begin{array}{l}0.803^{* * *} \\
(2.82)\end{array}$ & $\begin{array}{l}0.704^{* * *} \\
(2.98)\end{array}$ \\
\hline Quality of fiscal adjustment & $\begin{array}{l}-0.294^{\star * *} \\
(-2.92)\end{array}$ & $\begin{array}{l}-0.298^{\star * *} \\
(-2.75)\end{array}$ & $\begin{array}{l}-0.289^{\star \star *} \\
(-2.63)\end{array}$ & $\begin{array}{l}-0.279^{\star \star \star} \\
(-2.60)\end{array}$ & $\begin{array}{l}-0.299^{* * *} \\
(-2.91)\end{array}$ & $\begin{array}{l}-0.277^{* * *} \\
(-2.85)\end{array}$ & $\begin{array}{l}-0.288^{\star * *} \\
(-2.47)\end{array}$ & $\begin{array}{l}-0.292^{\star \star *} \\
(-2.90)\end{array}$ & $\begin{array}{l}-0.264^{\star * *} \\
(-2.92)\end{array}$ & $\begin{array}{l}-0.258^{\star \star \star} \\
(-2.76)\end{array}$ & $\begin{array}{l}-0.259^{* * *} \\
(-2.12)\end{array}$ & $\begin{array}{l}-0.258^{* \star \star} \\
(-2.99)\end{array}$ \\
\hline Quality of adjustment ${ }^{\star}$ Size of adjustment & $\begin{array}{l}0.159^{* * *} \\
(2.86)\end{array}$ & $\begin{array}{l}0.164^{* * *} \\
(3.01)\end{array}$ & $\begin{array}{l}0.162^{* * *} \\
(2.99)\end{array}$ & $\begin{array}{l}0.153^{* * *} \\
(2.86)\end{array}$ & $\begin{array}{l}0.165^{\star * *} \\
(3.01)\end{array}$ & $\begin{array}{l}0.167^{* *} \\
(2.96)\end{array}$ & $\begin{array}{l}0.178^{* *} \\
(2.02)\end{array}$ & $\begin{array}{l}0.177^{* * *} \\
(2.43)\end{array}$ & $\begin{array}{l}0.142^{* *} \\
(2.17)\end{array}$ & $\begin{array}{l}0.151^{\star *} \\
(2.16)\end{array}$ & $\begin{array}{l}0.165^{* *} \\
(2.01)\end{array}$ & $\begin{array}{l}0.168^{* *} \\
(2.19)\end{array}$ \\
\hline OECD country & $\begin{array}{l}-1.356^{\star \star \star} \\
(-3.10)\end{array}$ & $\begin{array}{l}-1.812^{* \star *} \\
(-3.58)\end{array}$ & $\begin{array}{l}-1.167^{* * *} \\
(-2.65)\end{array}$ & $\begin{array}{l}-1.001^{* * *} \\
(-2.70)\end{array}$ & $\begin{array}{l}-1.044^{* *} \\
(-1.93)\end{array}$ & $\begin{array}{l}-1.030^{* * *} \\
(-2.23)\end{array}$ & $\begin{array}{l}-1.135^{\star * *} \\
(-2.24)\end{array}$ & $\begin{array}{l}-1.511^{* * *} \\
(-3.34)\end{array}$ & $\begin{array}{l}-1.514^{* * *} \\
(-3.30)\end{array}$ & $\begin{array}{l}-1.105^{\star * *} \\
(-3.31)\end{array}$ & $\begin{array}{l}-1.201^{* * *} \\
(3.45)\end{array}$ & $\begin{array}{l}-1.679^{* * *} \\
(-3.44)\end{array}$ \\
\hline Private investment & $\begin{array}{l}-0.011^{* \wedge * *} \\
(-2.21)\end{array}$ & $\begin{array}{l}-0.019^{* * *} \\
(-2.91)\end{array}$ & $\begin{array}{l}-0.017^{* *} \\
(-1.99)\end{array}$ & $\begin{array}{l}-0.018^{\star *} \\
(-2.01)\end{array}$ & $\begin{array}{l}-0.021^{* * *} \\
(-2.59)\end{array}$ & $\begin{array}{l}-0.022^{\star * *} \\
(2.87)\end{array}$ & $\begin{array}{l}-0.024^{* * *} \\
(2.94)\end{array}$ & $\begin{array}{l}-0.032^{* * *} \\
(3.01)\end{array}$ & $\begin{array}{l}-0.011^{* *} \\
(-2.09)\end{array}$ & $\begin{array}{l}-0.015^{\star \star *} \\
(2.07)\end{array}$ & $\begin{array}{l}-0.011^{* * *} \\
(2.04)\end{array}$ & $\begin{array}{l}-0.012^{\star * *} \\
(2.12)\end{array}$ \\
\hline Interest rate of bank deposits & $\begin{array}{l}0.008^{*} \\
(1.82)\end{array}$ & $\begin{array}{l}0.008^{*} \\
(1.84)\end{array}$ & $\begin{array}{l}0.005^{*} \\
(1.89)\end{array}$ & $\begin{array}{l}0.008^{*} \\
(1.85)\end{array}$ & $\begin{array}{l}0.011^{*} \\
(1.84)\end{array}$ & $\begin{array}{l}0.016^{*} \\
(1.93)\end{array}$ & $\begin{array}{l}0.020^{* *} \\
(1.95)\end{array}$ & $\begin{array}{l}0.009^{* *} \\
(1.96)\end{array}$ & $\begin{array}{l}0.006^{*} \\
(1.75)\end{array}$ & $\begin{array}{l}0.007^{*} \\
(1.78)\end{array}$ & $\begin{array}{l}0.008^{*} \\
(1.89)\end{array}$ & $\begin{array}{l}0.007^{* *} \\
(1.98)\end{array}$ \\
\hline Change in tax revenues $1 /$ & $\begin{array}{l}-0.617^{* \star *} \\
(-3.99)\end{array}$ & & & & $\begin{array}{l}-0.624^{* * *} \\
(-4.01)\end{array}$ & & & & $\begin{array}{l}-0.611^{* * *} \\
(-3.92)\end{array}$ & & & \\
\hline Change in goods \& services expenditures $1 /$ & & $\begin{array}{l}0.333^{* *} \\
(3.02)\end{array}$ & & & & $\begin{array}{l}0.342^{\star * *} \\
(3.31)\end{array}$ & & & & $\begin{array}{l}0.322^{\star * *} \\
(2.98)\end{array}$ & & \\
\hline Change in transfers expenditures $1 /$ & & & $\begin{array}{l}0.222^{* * *} \\
(2.91)\end{array}$ & & & & $\begin{array}{l}0.228^{* * *} \\
(2.98)\end{array}$ & & & & $\begin{array}{l}0.219^{* * *} \\
(2.88)\end{array}$ & \\
\hline Change in public investment expenditures $1 /$ & & & & $\begin{array}{l}0.198^{* * *} \\
(2.78)\end{array}$ & & & & $\begin{array}{l}0.202^{\star * *} \\
(2.88)\end{array}$ & & & & $\begin{array}{l}0.157^{* * *} \\
(2.71)\end{array}$ \\
\hline Constant & $\begin{array}{l}-6.023^{* \star *} \\
(-3.10)\end{array}$ & $\begin{array}{l}-5.560^{* * *} \\
(-2.66)\end{array}$ & $\begin{array}{l}-7.020^{\star * *} \\
(-3.58)\end{array}$ & $\begin{array}{l}-8.204^{\star * *} \\
(-5.58)\end{array}$ & $\begin{array}{l}-6.920^{\star * *} \\
(10.71)\end{array}$ & $\begin{array}{l}-5.560^{\star * *} \\
(-2.62)\end{array}$ & $\begin{array}{l}-8.170^{\star * \star} \\
(-2.87)\end{array}$ & $\begin{array}{l}-7.221^{* * *} \\
(-4.42)\end{array}$ & $\begin{array}{l}-2.269^{\star * *} \\
(2.96)\end{array}$ & $\begin{array}{l}-5.100^{\star * *} \\
(-3.24)\end{array}$ & $\begin{array}{l}-7.104^{\star * *} \\
(-2.89)\end{array}$ & $\begin{array}{l}-6.012^{\star * *} \\
(-4.86)\end{array}$ \\
\hline Wald chi2 & 45.40 & 42.60 & 49.62 & 50.38 & 47.50 & 38.67 & 37.33 & 40.76 & 50.31 & 53.42 & 52.14 & 58.34 \\
\hline No. of failures & 43 & 42 & 43 & 43 & 33 & 32 & 32 & 33 & 49 & 49 & 48 & 49 \\
\hline Number of obs. & 432 & 432 & 445 & 445 & 543 & 542 & 542 & 543 & 362 & 362 & 361 & 362 \\
\hline
\end{tabular}

Source: Authors' calculations.

1/ Figures in percent of cyclically adjusted total revenues or total expenditures. Changes are calculated as follows: we subtract the value of the variable in the last year of the adjustment episode from its value in the first year in which the debt consolidation starts.

$\left({ }^{* *}\right)$ Significant at a 1 percent level; $\left({ }^{* *}\right)$ significant at a 5 percent level; $\left({ }^{*}\right)$ significant at a 10 percent level. 
Table 11. Parametric Estimation of Proportional Hazard Model: Robustness (4)—Non-Cyclical Adjustments

\begin{tabular}{|c|c|c|c|c|c|c|c|c|c|c|c|c|}
\hline \multirow{3}{*}{$\frac{\text { Duration }}{\text { Length of banking crisis }}$} & \multicolumn{4}{|c|}{100 percent threshold } & \multicolumn{4}{|c|}{50 percent threshold } & \multicolumn{4}{|c|}{10 percent threshold } \\
\hline & & & & & & Wei & bull & & & & & \\
\hline & $\begin{array}{l}0.150^{* * *} \\
(5.04)\end{array}$ & $\begin{array}{l}0.190^{\star \star \star} \\
(3.80)\end{array}$ & $\begin{array}{l}0.168^{\star \star *} \\
(5.14)\end{array}$ & $\begin{array}{l}0.156^{\star * *} \\
(4.46)\end{array}$ & $\begin{array}{l}0.160^{\star \star *} \\
(3.16)\end{array}$ & $\begin{array}{l}0.132^{\star \star \star} \\
(4.61)\end{array}$ & $\begin{array}{l}0.163^{\star \star \star} \\
(3.12)\end{array}$ & $\begin{array}{l}0.169^{* \star *} \\
(2.43)\end{array}$ & $\begin{array}{l}0.174^{* * *} \\
(3.22)\end{array}$ & $\begin{array}{l}0.188^{* * *} \\
(3.40)\end{array}$ & $\begin{array}{l}0.140^{* * *} \\
(3.52)\end{array}$ & $\begin{array}{l}0.139^{* \star *} \\
(2.88)\end{array}$ \\
\hline Accumulated debt during banking crisis & $\begin{array}{l}0.832^{* * *} \\
(2.90)\end{array}$ & $\begin{array}{l}0.801^{* * *} \\
(2.47)\end{array}$ & $\begin{array}{l}0.822^{* *} \\
(2.95)\end{array}$ & $\begin{array}{l}0.888^{* * *} \\
(2.65)\end{array}$ & $\begin{array}{l}0.942^{* * *} \\
(2.60)\end{array}$ & $\begin{array}{l}0.900^{* * *} \\
(2.63)\end{array}$ & $\begin{array}{l}0.821^{* * *} \\
(2.98)\end{array}$ & $\begin{array}{l}0.911^{* * *} \\
(3.20)\end{array}$ & $\begin{array}{l}0.824^{* * *} \\
(3.25)\end{array}$ & $\begin{array}{l}0.812^{\star * *} \\
(3.22)\end{array}$ & $\begin{array}{l}0.811^{* * *} \\
(3.18)\end{array}$ & $\begin{array}{l}0.824^{* * *} \\
(3.25)\end{array}$ \\
\hline Quality of fiscal adjustment (non-cyclically adjusted) & $\begin{array}{l}-0.299^{* * *} \\
(2.91)\end{array}$ & $\begin{array}{l}-0.277^{* * *} \\
(2.85)\end{array}$ & $\begin{array}{l}-0.288^{\star \star *} \\
(2.47)\end{array}$ & $\begin{array}{l}-0.292^{\star \star \star} \\
(2.90)\end{array}$ & $\begin{array}{l}-0.294^{\star * *} \\
(2.92)\end{array}$ & $\begin{array}{l}-0.298^{* \star *} \\
(2.75)\end{array}$ & $\begin{array}{l}-0.289^{* * *} \\
(2.63)\end{array}$ & $\begin{array}{l}-0.279^{* * *} \\
(-2.60)\end{array}$ & $\begin{array}{l}-0.264^{\star * \star} \\
(-2.11)\end{array}$ & $\begin{array}{l}-0.258^{* \star *} \\
(-2.89)\end{array}$ & $\begin{array}{l}-0.259^{* * *} \\
(-2.92)\end{array}$ & $\begin{array}{l}-0.258^{* \star *} \\
(-2.93)\end{array}$ \\
\hline $\begin{array}{l}\text { Quality of adjustment*Size of adjustment (non-cyclically } \\
\text { adjusted) }\end{array}$ & $\begin{array}{l}0.142^{* \star} \\
(2.07)\end{array}$ & $\begin{array}{l}0.151^{* * *} \\
(2.86)\end{array}$ & $\begin{array}{l}0.165^{\star \star *} \\
(3.01)\end{array}$ & $\begin{array}{l}0.168^{* \star *} \\
(2.99)\end{array}$ & $\begin{array}{l}0.182^{* *} \\
(2.10)\end{array}$ & $\begin{array}{l}0.165^{*} \\
(1.89)\end{array}$ & $\begin{array}{l}0.141^{* *} \\
(2.13)\end{array}$ & $\begin{array}{l}0.137^{*} \\
(1.82)\end{array}$ & $\begin{array}{l}0.187^{* *} \\
(2.07)\end{array}$ & $\begin{array}{l}0.167^{* *} \\
(2.06)\end{array}$ & $\begin{array}{l}0.178^{\star *} \\
(2.01)\end{array}$ & $\begin{array}{l}0.177^{* *} \\
(2.19)\end{array}$ \\
\hline OECD country & $\begin{array}{l}-1.124^{* *} \\
(-2.03)\end{array}$ & $\begin{array}{l}-1.031^{\star * *} \\
(-2.31)\end{array}$ & $\begin{array}{l}-1.122^{* * *} \\
(-2.24)\end{array}$ & $\begin{array}{l}-1.512^{\star \star \star} \\
(-3.34)\end{array}$ & $\begin{array}{l}-1.333^{* * *} \\
(-3.18)\end{array}$ & $\begin{array}{l}-1.804^{* * *} \\
(-3.55)\end{array}$ & $\begin{array}{l}-1.167^{* * *} \\
(-2.65)\end{array}$ & $\begin{array}{l}-1.123^{* * *} \\
(-2.98)\end{array}$ & $\begin{array}{l}-1.114^{* * *} \\
(-3.33)\end{array}$ & $\begin{array}{l}-1.115^{\star \star *} \\
(-3.34)\end{array}$ & $\begin{array}{l}-1.331^{* * *} \\
(3.67)\end{array}$ & $\begin{array}{l}-1.023^{* * *} \\
(-3.41)\end{array}$ \\
\hline Private investment & $\begin{array}{l}-0.021^{* * *} \\
(-2.59)\end{array}$ & $\begin{array}{l}-0.022^{\star \star *} \\
(2.87)\end{array}$ & $\begin{array}{l}-0.024^{\star * *} \\
(2.94)\end{array}$ & $\begin{array}{l}-0.032^{* * *} \\
(3.01)\end{array}$ & $\begin{array}{l}-0.011^{*} \\
(-2.01)\end{array}$ & $\begin{array}{l}-0.019^{*} \\
(-1.91)\end{array}$ & $\begin{array}{l}-0.017^{*} \\
(-1.92)\end{array}$ & $\begin{array}{l}-0.018^{* *} \\
(-2.01)\end{array}$ & $\begin{array}{l}-0.011^{* *} \\
(-2.09)\end{array}$ & $\begin{array}{l}-0.015^{\star * *} \\
(2.07)\end{array}$ & $\begin{array}{l}-0.011^{* * *} \\
(2.04)\end{array}$ & $\begin{array}{l}-0.012^{\star \star *} \\
(2.12)\end{array}$ \\
\hline Interest rate of bank deposits & $\begin{array}{l}0.012^{* *} \\
(1.96)\end{array}$ & $\begin{array}{l}0.016^{*} \\
(1.95)\end{array}$ & $\begin{array}{l}0.022^{*} \\
(1.65)\end{array}$ & $\begin{array}{l}0.019^{\star *} \\
(1.98)\end{array}$ & $\begin{array}{l}0.018^{*} \\
(1.82)\end{array}$ & $\begin{array}{l}0.011^{*} \\
(1.84)\end{array}$ & $\begin{array}{l}0.005^{\star} \\
(1.89)\end{array}$ & $\begin{array}{l}0.007^{*} \\
(1.88)\end{array}$ & $\begin{array}{l}0.012^{*} \\
(1.85)\end{array}$ & $\begin{array}{l}0.011^{*} \\
(1.92)\end{array}$ & $\begin{array}{l}0.011^{*} \\
(1.94)\end{array}$ & $\begin{array}{l}0.010^{* *} \\
(1.96)\end{array}$ \\
\hline Change in non-cyclically adjusted tax revenues $1 /$ & $\begin{array}{l}-0512^{* * *} \\
(-3.25)\end{array}$ & & & & $\begin{array}{l}-0.492^{\star * *} \\
(-2.99)\end{array}$ & & & & $\begin{array}{l}-0.481^{* * *} \\
(-2.98)\end{array}$ & & & \\
\hline $\begin{array}{l}\text { Change in non-cyclically adjusted goods \& services } \\
\text { expenditures } 1 /\end{array}$ & & $\begin{array}{l}0.136^{\star \star \star} \\
(2.95)\end{array}$ & & & & $\begin{array}{l}0.133^{\star * *} \\
(2.87)\end{array}$ & & & & $\begin{array}{l}0.124^{* * *} \\
(2.46)\end{array}$ & & \\
\hline Change in non-cyclically adjusted transfers expenditures $1 /$ & & & $\begin{array}{l}0.200^{\star \star} \\
(2.32)\end{array}$ & & & & $\begin{array}{l}0.148^{\star \star} \\
(2.36)\end{array}$ & & & & $\begin{array}{l}0.115^{\star *} \\
(2.31)\end{array}$ & \\
\hline $\begin{array}{l}\text { Change in non-cyclically adjusted public investment } \\
\text { expenditures } 1 /\end{array}$ & & & & $\begin{array}{l}0.124^{\star * *} \\
(2.98)\end{array}$ & & & & $\begin{array}{l}0.122^{\star \star \star} \\
(2.85)\end{array}$ & & & & $\begin{array}{l}0.120^{\star \star \star} \\
(2.68)\end{array}$ \\
\hline Constant & $\begin{array}{l}-6.920^{\star * *} \\
(10.71)\end{array}$ & $\begin{array}{l}-5.560^{* * *} \\
(-2.62)\end{array}$ & $\begin{array}{l}-8.170^{* * *} \\
(-2.87)\end{array}$ & $\begin{array}{l}-7.221^{* * *} \\
(-4.42)\end{array}$ & $\begin{array}{l}-6.023^{* * *} \\
(-3.10)\end{array}$ & $\begin{array}{l}-5.560^{* * *} \\
(-2.66)\end{array}$ & $\begin{array}{l}-7.020^{* * *} \\
(-3.58)\end{array}$ & $\begin{array}{l}-8.204^{* * *} \\
(-5.58)\end{array}$ & $\begin{array}{l}-2.269^{\star \star *} \\
(2.96)\end{array}$ & $\begin{array}{l}-5.100^{\star * *} \\
(-3.24)\end{array}$ & $\begin{array}{l}-7.104^{\star * *} \\
(-2.89)\end{array}$ & $\begin{array}{l}-6.012^{* * *} \\
(-4.86)\end{array}$ \\
\hline Wald chi2 & 47.50 & 38.67 & 37.33 & 40.76 & 45.40 & 42.60 & 49.62 & 50.38 & 50.31 & 53.42 & 52.14 & 58.34 \\
\hline No. of failures & 33 & 32 & 32 & 33 & 43 & 42 & 43 & 43 & 49 & 49 & 48 & 49 \\
\hline Number of obs. & 543 & 542 & 542 & 543 & 432 & 432 & 445 & 445 & 362 & 362 & 361 & 362 \\
\hline
\end{tabular}

\section{Source: Authors' calculations.}

1/ Figures in percent of not cyclically adjusted total revenues or total expenditures (not cyclically adjusted). Changes are calculated as follows: we subtract the value of the variable in the last year of the adjustment episode from its value in the first year in which the debt consolidation starts.

$\left(^{* * *}\right)$ Significant at a 1 percent level; $\left({ }^{* *}\right)$ significant at a 5 percent level; $\left({ }^{*}\right)$ significant at a 10 percent level. 
Table 12. Parametric Estimation of Continuous Model: Robustness (5) - Change in Debt-to-GDP Ratio in the Aftermath of the Crisis (Ihs) $1 /$

\begin{tabular}{|c|c|c|c|c|c|c|c|c|c|}
\hline \multirow[b]{2}{*}{ Reduction in Debt Ratio } & \multicolumn{3}{|c|}{$\begin{array}{c}\text { Debt Reduction } \\
100 \text { percent threshold }\end{array}$} & \multicolumn{3}{|c|}{$\begin{array}{c}\text { Debt Reduction } \\
50 \text { percent threshold }\end{array}$} & \multicolumn{3}{|c|}{$\begin{array}{l}\text { Debt Reduction } \\
10 \text { percent threshold }\end{array}$} \\
\hline & OLS & Fixed Effects & PCSE & OLS & Fixed Effects & PCSE & OLS & Fixed Effects & PCSE \\
\hline \multirow[t]{2}{*}{ Length of banking crisis } & $-0.168^{\star * \star}$ & $-0.124^{\star * \star}$ & $-0.142^{\star \star \star}$ & $-0.140^{\star * *}$ & $-0.175^{\star \star \star}$ & $-0.117^{\star * *}$ & $-0.164^{\star * *}$ & $-0.115^{\star * \star}$ & $-0.116^{\star \star \star}$ \\
\hline & $(-4.43)$ & $(-3.76)$ & $(-2.13)$ & $(-4.01)$ & $(-3.14)$ & $(-2.42)$ & $(-4.42)$ & $(-3.46)$ & $(-2.27)$ \\
\hline \multirow[t]{2}{*}{ Accumulated debt during banking crisis } & $-0.971^{\star \star *}$ & $-0.825^{\star \star \star}$ & $-0.811^{* \star *}$ & $-0.710^{\star \star *}$ & $-0.902^{\star \star \star}$ & $-0.930^{* \star *}$ & $-0.970^{* \star *}$ & $-0.932^{\star * \star}$ & $-0.828^{\star * *}$ \\
\hline & $(-2.65)$ & $(-2.99)$ & $(-2.81)$ & $(-2.82)$ & $(-2.52)$ & $(-2.51)$ & $(-2.62)$ & $(-2.55)$ & $(-2.99)$ \\
\hline \multirow[t]{2}{*}{ Quality of fiscal adjustment } & $0.263^{* *}$ & $0.259^{*}$ & $0.272^{* *}$ & $0.273^{* * *}$ & $0.280^{* * *}$ & $0.250^{\star \star *}$ & $0.162^{* * *}$ & $0.151^{* * *}$ & $0.185^{\star * *}$ \\
\hline & $(2.26)$ & $(2.08)$ & $(2.22)$ & $(2.82)$ & $(2.33)$ & $(2.72)$ & $(3.90)$ & $(3.88)$ & $(3.92)$ \\
\hline \multirow[t]{2}{*}{ Quality of adjustment*Size of adjustment } & $-0.166^{\star * *}$ & $-0.144^{\star * *}$ & $-0.133^{* * *}$ & $-0.134^{\star *}$ & $-0.122^{\star *}$ & $-0.128^{\star *}$ & $-0.154^{*}$ & $-0.178^{* *}$ & $-0.166^{*}$ \\
\hline & $(-2.17)$ & $(-2.19)$ & $(-2.24)$ & $(-1.98)$ & $(-2.12)$ & $(-2.16)$ & $(-1.88)$ & $(-2.01)$ & $(-1.89)$ \\
\hline \multirow[t]{2}{*}{ OECD country } & $1.820^{* * *}$ & $1.020^{* *}$ & $1.101^{* * *}$ & $1.102^{\star * \star}$ & $1.166^{* \star *}$ & $1.582^{\star \star \star}$ & $1.823^{* * *}$ & $1.580^{* * *}$ & $1.061^{* *}$ \\
\hline & $(3.62)$ & $(2.16)$ & $(2.45)$ & $(2.43)$ & $(2.67)$ & $(3.55)$ & $(3.65)$ & $(3.52)$ & $(1.98)$ \\
\hline \multirow[t]{2}{*}{ Private investment } & $0.011^{* \star *}$ & $0.015^{\star *}$ & $0.018^{\star \star \star}$ & $0.007^{* *}$ & $0.009^{* *}$ & $0.016^{* *}$ & $0.008^{*}$ & $0.013^{*}$ & $0.010^{* *}$ \\
\hline & $(2.39)$ & $(2.18)$ & $(2.43)$ & $(2.04)$ & $(2.12)$ & $(2.22)$ & $(1.95)$ & $(1.92)$ & $(1.93)$ \\
\hline \multirow[t]{2}{*}{ Interest rate of bank deposits } & $-0.017^{*}$ & $-0.018^{*}$ & $-0.016^{\star *}$ & $-0.015^{\star \star}$ & $-0.013^{\star \star}$ & $-0.011^{\star *}$ & $-0.016^{*}$ & $-0.019^{\star *}$ & $-0.012^{\star \star}$ \\
\hline & $(-1.74)$ & $(-1.76)$ & $(-1.88)$ & $(-1.88)$ & $(-1.79)$ & $(-1.99)$ & $(-1.54)$ & $(-1.97)$ & $(-1.96)$ \\
\hline \multirow[t]{2}{*}{ Constant } & $5.006^{* * *}$ & $3.920^{* * *}$ & $4.106^{\star * *}$ & $4.034^{* * *}$ & $3.992^{* * *}$ & $4.002^{\star *}$ & $5.506^{* * *}$ & $3.924^{\star *}$ & $4.118^{* *}$ \\
\hline & $(5.28)$ & $(2.99)$ & $(3.72)$ & $(3.22)$ & $(2.89)$ & $(2.90)$ & $(5.18)$ & $(2.92)$ & $(2.19)$ \\
\hline Prob. F-Test & 0.000 & 0.000 & 0.000 & 0.000 & 0.000 & 0.000 & 0.000 & 0.000 & 0.000 \\
\hline R-Squared & 0.58 & 0.65 & 0.77 & 0.65 & 0.61 & 0.63 & 0.65 & 0.72 & 0.73 \\
\hline Number of obs. & 564 & 562 & 561 & 564 & 562 & 561 & 564 & 562 & 561 \\
\hline
\end{tabular}

Source: Authors' calculations.

$1 /$ Change in the ratio of debt-to-GDP in the ten years after the end of the crisis.

$\left({ }^{* * *}\right)$ Significant at a 1 percent level; $\left(^{* *}\right)$ significant at a 5 percent level; $\left({ }^{\star}\right)$ significant at a 10 percent level 


\section{Conclusions}

Many countries around the world have accumulated large public debts in the aftermath of the recent banking crisis. As the economies recover from the recession, the challenge for governments is to regain fiscal stability by unwinding the exceptional fiscal stimulus when economic conditions permit and reducing public debt. The unprecedented simultaneous increase in public debt levels worldwide, however, makes this effort particularly demanding. This paper focused on factors that explain successful public debt consolidations following 100 episodes of banking crises during 1980-2008 using survival analysis. We find that debt consolidation is less successful when countries are hit by longer-lasting (and thus more severe) banking crises. This reflects higher uncertainty and permanent output losses resulting from these crises that make fiscal consolidation more challenging.

Successful debt consolidations are in general more likely when they are based on cuts in current expenditures. Accompanying policies are important; when monetary conditions are allowed to remain accommodative and risk premia are contained, debt reduction is more likely to be achieved: a key lesson for countries exiting the crisis and preparing to unwind fiscal and monetary support. This result also highlights the importance of credible fiscal adjustment strategies that anchor market expectations about fiscal sustainability. Lack of credibility can make debt reduction much harder to achieve and lead to potential selffulfilling expectations about rising solvency risks.

In contrast with the previous literature on fiscal consolidations, we find that raising tax revenues is important for debt reduction in countries with large consolidation needs. This reflects the large size of fiscal adjustment required in postcrisis periods and the need to maintain a balance between expenditure savings and revenue-raising measures to sustain the consolidation efforts long enough to bring debt under control. An appropriate fiscal policy mix would also help reduce economic inefficiency that hamper growth and would boost the credibility of fiscal consolidation thereby contributing to tighter credit risk spreads. However, higher taxation should not harm efficiency and has to minimize distortions, particularly in countries with high tax ratios. Simplifying the tax system by reducing excessive tax rates and broadening the tax base could help enhance revenue collection while shifting the burden of taxes from income and capital to consumption, pollution and property taxes could help reduce distortions (IMF, 2010).

Overall, fiscal adjustment can be complex in the aftermath of banking crises, requiring supporting actions to revive growth. In such circumstances, debt consolidations should rely on a combination of improvements in the primary balance and sustained economic growth. The former should be achieved by a combined strategy of revenue increases and expenditure savings while preserving productive investment. The latter requires implementation of structural reforms to enhance productivity as well as measures to reduce economic distortions in the economy. Improving the budget composition could be an additional important ingredient in the strategy to support growth by removing efficiency harming distortions and raising labor supply and savings. 


\section{Appendix I. Survival Analysis Model}

This appendix describes the econometric methodology used in the paper using survival analysis techniques adapted to a sample of banking crisis episodes and postcrisis fiscal adjustments.

We define $T$ as the discrete random variable that measures the time between the beginning of a debt consolidation and its end due to successfully achieving the target debt level, the observations consist of a series of data $\left(t_{1}, t_{2}, \ldots t_{n}\right)$ which correspond to the observed durations of each consolidation period in the sample. The probability distribution of the duration variable can be specified by the cumulative distribution function

$$
F(t)=\operatorname{Pr}(T<t)
$$

which indicates the probability that the random variable $T$ is smaller than a certain value $t$. The corresponding probability function is then

$$
P(t)=\operatorname{Pr}(T=t)
$$

In duration models, two main functions are used to characterize the probability distribution of the duration variable:

(a) The survivor function is defined as:

$$
S(t)=\operatorname{Pr}(T \geq t)=1-F(t)
$$

and it gives the probability that the duration of the debt consolidation is greater than or equal to $t$.

(b) The hazard function is defined as

$$
h(t)=\operatorname{Pr}(T=t / T \geq t)
$$

and it provides, for each duration, the probability of successfully ending a consolidation episode, conditioned on the duration of the consolidation.

There is a relation between both functions given by the following expression:

$$
S(t)=\prod_{s=1 \mid t}(1-h(s))
$$

In the literature, the model that has usually been used to characterize the hazard function in the parametric estimations of survival analyses is the Model of Proportional Hazard (PH), which assumes that the hazard function can be split as follows:

$$
h(t, X)=h_{0}(t) * g(X)
$$


where $h_{o}(t)$ is the baseline hazard function that captures the dependency of data to duration, and $g(X)$ is a function of individual variables. This function of explanatory variables is a negative function usually defined as $g(X)=\exp \left(X^{\prime} \beta\right)$.

This model can be estimated firstly without imposing any specific functional form to the baseline hazard function, following the Cox Model (1972): ${ }^{26}$

$$
h(t, X)=h_{0}(t) * \exp \left(X^{\prime} \beta\right)
$$

An alternative is to impose a specific parametric form to the function $h_{0}(t)$. In this case, the models most commonly used are the Weibull Model and the Exponential Model. In the first one, $h o(t)=p t^{p-1}$, where $p$ is a parameter that has to be estimated. When $p=1$, the Weibull Model is equal to the Exponential Model, where there is no dependency on duration. On the other hand, when the parameter $p>1$, there exists a positive dependency on duration, and a negative dependency when $p<1$. Therefore, by estimating $p$, it is possible to test the hypothesis of duration dependency of debt consolidations.

Once equation (7) has been estimated the following residuals can be calculated:

$$
\hat{e}=-\log S(t / x)
$$

where $S(t / x)$ is the estimated probability of surviving to time t. If the fitted model is correct, these residuals, which are always positive, should have a standard censored exponential distribution with hazard ratio equal to 1 . We can assess the model's fit by calculating, based for example on the Kaplan-Meier survival estimates an empirical estimate of the cumulative hazard function, using these Cox-Snell residuals as the time variable. If the model fits the data, then the plot of the cumulative hazard versus the residuals in equation (8) should be a straight line with slope equal to unity and beginning at the origin.

\footnotetext{
${ }^{26}$ Mathematically, the baseline hazard function, $h o(t)$, is defined for all time $t$ in which a change has taken place, and it is not defined for other moments of time. But the survivor function $S_{0}(t)$ is defined for all values of $t$.
} 


\section{References}

Alesina, Alberto, and Silvia Ardagna, 1998, "Tales of Fiscal Contractions: Fiscal Adjustments: Why Can They Be Expansionary,” Economic Policy, 27, pp. 489-543.

Alesina, Alberto, Silvia Ardagna, Roberto Perotti, and Fabrizio Schiantarelli, 1999, "Fiscal Policy, Profits, and Investment," NBER Working Paper, No. 7207.

Alesina, Alberto, Gerald D. Cohen, and Nouriel Roubini, 1992, "Macroeconomic Policies and Elections in OECD Democracies," Economics and Politics, Vol. 4, pp. 1-30.

Alesina, Alberto, and Roberto Perotti, 1995, "Fiscal Expansion and Fiscal Adjustments in OECD Countries," Economic Policy, Vol. 21, pp. 205-48.

Alesina, Alberto, and Roberto Perotti, 1996, "Budget Deficits and Budget Institutions," NBER Working Papers 5556.

Alesina, Alberto., Perotti R., and Jose Tavares, 1998, “The Political Economy of Fiscal Adjustments," Brookings Papers on Economic Activity, Vol. 1, pp. 197-248.

Alesina, Alberto, and Silvia Ardagna, 2009, "Large Changes in Fiscal Policy: Taxes Versus Spending," Paper presented at the Tax Policy and the Economy Conference.

Baldacci, Emanuele, Sanjeev Gupta, and Carlos Mulas-Granados, 2009, "How Effective is Fiscal Policy Response in Systemic Banking Crises,” IMF Working Paper 09/160 (Washington: International Monetary Fund).

Baldacci, Emanuele, and Manmohan Kumar, "Fiscal Deficits, Public Debt, and Sovereign Bond Yields,” IMF Working Paper 10/184 (Washington: International Monetary Fund).

Barro, Robert, 1995, “Optimal Debt Management,” NBER Working Paper No. 5327.

Baunsgaard, Thomas, and Steven A. Symansky, 2009, “Automatic Fiscal Stabilizers,” IMF Staff Position Note, 09/23 (Washington: International Monetary Fund).

Berg, Andrew, and Jeffrey Sachs, 1988, "Debt Crisis: Structural Explanations of Country Performance," Journal of Development Economics, Vol. 29, pp. 271-306.

Blanchard, Olivier, 1990, "Suggestions for a New Set of Fiscal Indicators," OECD Working Paper, No. 79.

Bohn, Henning, 1995, "The Sustainability of Budget Deficits in a Stochastic Economy," Journal of Money, Credit, and Banking, Vol. 27, No. 2, pp. 252-72. 
Buti, Marco, and Paul van den Noord, 2003, "Discretionary Fiscal Policy and Elections: The Experience of the Early Years of EMU." OECD Economics Department Working Paper, ECO/WKP (2003) pp. 5.

Calvo, Guillermo, 1988, "Servicing the Public Debt: the Role of Expectations," American Economic Review Vol. 78, No. 4, pp. 647-61.

Cassimon, Danny, Blanca Moreno-Dodson, and Quentin Wodon, 2008, "Debt Sustainability for Low-Income Countries: a Review of Standard and Alternative Concepts," in Public Finance for Poverty Reduction: Concepts and Case Studies from Africa and Latin America, eds. Blanca Moreno-Dodson and Quentin Wodon (Washington: World Bank), pp. 21-56.

Celasun, Oya, Xavier Debrun, and Jonathan D. Ostry, 2006, "Primary Surplus Behavior and Risks to Fiscal Sustainability in Emerging Market Countries: A 'Fan-Chart' Approach,” IMF Working Paper, 06/67 (Washington: International Monetary Fund).

Chalk, Nigel, and Richard Hemming, 2000, “Assessing Fiscal Sustainability in Theory and Practice," IMF Working Paper No. 00/81 (Washington: International Monetary Fund).

Conway, Patrick, 2000, "IMF Programs and External Balance: the Crisis-Participation Dynamic” (Chapel Hill: University of North Carolina).

Cottarelli, Carlo, and Andrea Schaecther, 2010," Long-Term Trends in public Finances in the G-7 Economies," IMF Staff Position Note, 10/13 (Washington: International Monetary Fund).

Cottarelli, Carlo, and Jose Viñals, 2009, "A Strategy for Renormalizing Fiscal and Monetary Policies in Advanced Economies," IMF Staff Position Note, 09/22 (Washington: International Monetary Fund).

Cuddington, John T., 1997, "Analyzing the Sustainability of Fiscal Deficits in Developing Countries,” World Bank Policy Research Working Paper No. 1784 (Washington: World Bank).

Diaz Alvarado, Carlos, Alejandro Izquierdo, and Ugo Panizza, 2004, "Fiscal Sustainability in Emerging Market Countries with an Application to Ecuador," IDB Working Paper No. 511 (Washington: Inter-American Development Bank).

Easterly, William, 2001, "Growth Implosions and Debt Explosions: Do Growth Slowdowns Cause Public Debt Crises?” Contributions to Macroeconomics.

Edwards, Sebastian, 2002, "Debt Relief and Fiscal Sustainability,” NBER Working Paper No. 8939. 
European Commission, 2007, Public Finance Report in EM-2007, Part IV: Lesson From Successful Fiscal Consolidations, European Economy, No. 3, Reports and Studies (Brussels: European Commission).

Frydl, Edward J., 1999, “The Length and Cost of Banking Crises,” IMF Working Paper 99/30 (Washington: International Monetary Fund).

Giavazzi, Francesco, and Marco Pagano, 1990, "Can Severe Fiscal Contractions be Expansionary?” NBER Macroeconomics Annual, pp. 75-116.

Giavazzi, Francesco., Tullio Jappelli, and Marco Pagano, 2000, "Searching for Non-Linear Effects of Fiscal Policy: Evidence from Industrial and Developing countries," National Bureau of Economic Research. Working Paper Series, No. 7460, pp. 1-36.

Grilli, Vittorio, Donato Masciandaro, and Guido Tabellini, 1991 "Institutions and Policies: Political and Monetary Institutions and Public Financial Policies in the Industrial Countries," Economic Policy, Vol. 13, 341-92.

Gupta, Sanjeev, Emanuele Baldacci, Benedict Clements, and Erwin Tiongson, 2005, "What Sustains Fiscal Consolidations in Emerging Market Countries?” International Journal of Finance and Economics, Vol.10, pp. 307-321.

Hallerberg, Mark, and Jurgen von Hagen, 1997, "Electoral Institutions, Cabinet Negotiations and Budget Deficits in the European Union (EU)," CEPR Working Paper, 1555.

Hamilton, J., and M. Flavin (1986), "On the Limitations of Government Borrowing: a Framework for Empirical Testing,” American Economic Review 76: pp. 809-819.

Haugh, David, Patrice Ollivaud, and David Turner, 2009, "What Drives Sovereign Risk Premiums? An Analysis of Recent Evidence From the Euro Area," Economic Department Working Paper, ECO/WKP (2009) pp. 59.

Horton, Mark, and Anna Ivanova, 2009, "The Size of the Fiscal Expansion: An Analysis for the Largest Countries," available via the internet: http://www.imf.org/external/np/pp/eng/2009/020109.pdf (Washington: International Monetary Fund).

Horton, Mark, Manmohan Kumar, and Paolo Mauro (2009) "The State of Public Finances: A Cross-Country Fiscal Monitor,” IMF Staff Position Note 09/21, pp. 49 (Washington: International Monetary Fund),

International Monetary Fund, 2009a, "From Recession to Recovery: How Soon and How Strong?” World Economic Outlook 2009, Chapter 3 (Washington: International Monetary Fund). 
International Monetary Fund 2009b, "Fiscal Implications of the Global and Financial Crisis," IMF Staff Position Note, SPN/09/13 (Washington: International Monetary Fund).

International Monetary Fund, 2009c, "Asia and Pacific. Building a Sustained Recovery." Regional Economic Outlook (Washington: International Monetary Fund).

International Monetary Fund, 2009d, "The State of Public Finances: A Cross-Country Fiscal Monitor. November 2009,” IMF Staff Position Note 09/25 (Washington: International Monetary Fund).

International Monetary Fund, 2009e, "Fiscal Rules: Anchoring Expectations for Sustainable Public Finances," (Washington: International Monetary Fund).

International Monetary Fund, 2010, IMF Fiscal Monitor, May 2010. Fiscal Challenges Beyond the Crisis, World Economic and Financial Surveys, (Washington: International Monetary Fund).

Kraay, Art, and Vikram Nehru, 2003, “When is Debt Sustainable?” (Washington: World Bank).

Krueger, Anne O., 1987, “Origins of the Developing Countries' Debt Crisis, 1970 to 1982," Journal of Development Economics, Vol. 27, pp. 165-87.

Laeven, Luc, and Fabian Valencia, 2008, “Systemic Banking Crises: a New Database,” IMF Working Paper 08/224 (Washington: International Monetary Fund).

Lambertini, Luc, and Jose Tavares, 2001, "Exchange Rates and Fiscal Adjustments: Evidence from the OECD and Implications for EMU," Boston College Working Paper, pp. 576.

Manasse, Paolo, and Nouriel Roubini, 2005, "Rules of Thumb" for Sovereign Debt Crises," IMF Working Paper No. 05/42 (Washington: International Monetary Fund).

Maroto, Reyes, and Carlos Mulas-Granados, 2002, "The Duration of Budgetary Consolidations in Europe," European Economy Group (UCM), Working Paper No. $18 / 2002$.

Maroto, Reyes, Carlos Mulas-Granados, 2007, "What Makes Fiscal Policy Sustainable? A Survival Analysis of Fiscal Consolidations in Europe," Public Choice, Vol.130, No. 3-4, pp. 24-46.

McDermott, John C., and Robert Wescott, 1996, “An Empirical Analysis of Fiscal Adjustments," IMF Staff Papers (Washington: International Monetary Fund).

Mulas-Granados, Carlos, 2003, "The Political and Economic Determinants of Fiscal Adjustments in Europe," European Political Economy Review, Vol. 1, No. 1, pp. 33-64. 
Mulas-Granados, Carlos, 2006, Economics, Politics, and Budgets: The Political Economy of Fiscal Consolidations in Europe, Palgrave-MacMillan Publishing, Co (Basingstoke and New York), pp. 316.

Mendoza, Enrique, and P. Marcelo Oviedo, 2003, "Public Debt Sustainability under Uncertainty,” (Washington: Inter-American Development Bank), mimeo.

Persson, Torsten, and Guido Tabellini, 1999, Political Economics and Public Finance, Handbook of Public Economics ed. by A. Auerbach and M. Feldstein, Vol. III (Amsterdam: North Holland).

Reinhart, Vincent, and Brian Sack, 2000, "The Economic Consequences of Disappearing Government Debt," Brookings Papers on Economic Activity, No. 2, 163-220, (2002), "Assessing Sustainability," mimeo (Washington: International Monetary Fund).

Rogoff, Kenneth S., and Carmen M. Reinhart, 2009, "The Aftermath of Financial Crises," NBER Working Paper, 14587.

Sutherland, Alan, 1997, "Fiscal Crises and Aggregate Demand: Can High Public Debt Reverse the Effects of Fiscal Policy?" Journal of Public Economics, Vol. 45, pp. 147-162.

United Nations, 2009, "The Impact of the Financial and Economic Crisis on Debt Sustainability in Developing Countries," UNCTAD Secretariat Note (New York: United Nations).

Von Hagen, Juergen, Andrews Hallett, and Rolf Strauch, 2001, "Budgetary Consolidation in EMU," Economics Papers, p. 148 (Brussels: European Commission).

Weingast, Barry, Kenneth Shepsle, and Christopher Johnson, 1981, “The Political Economy of Benefits and Costs: A Neoclassical Approach to Redistributive Politics," Journal of Political Economy, Vol. 89, pp. 642-64.

Wilcox, David W., 1989, "The Sustainability of Government Deficit: Implications of the Present-Value Borrowing Constraint," Journal of Money, Credit, and Banking, Vol. 21, No. 3, pp. 291-306. 